\title{
Effect of fecal microbiota transplant on symptoms of psychiatric disorders: a systematic review
}

\author{
Arthi Chinna Meyyappan ${ }^{1,2,3^{*}}$ (D) Evan Forth ${ }^{1,2,3}$, Caroline J. K. Wallace ${ }^{1,2,3}$ and Roumen Milev ${ }^{1,2,3,4}$
}

\begin{abstract}
Background: The Gut-Brain-Axis is a bidirectional signaling pathway between the gastrointestinal (GI) tract and the brain. The hundreds of trillions of microorganisms populating the gastrointestinal tract are thought to modulate this connection, and have far reaching effects on the immune system, central and autonomic nervous systems, and Gl functioning. These interactions Diagnostic and statistical manual of mental disorders have also been linked to various psychiatric illnesses such as depression, anxiety, substance abuse, autism spectrum disorder, and eating disorders. It is hypothesized that techniques aimed at strengthening and repopulating the gut microbiome, such as Fecal Microbiota Transplant (FMT), may be useful in the prevention and treatment of psychiatric illnesses.

Methods: A systematic search of five databases was conducted using key terms related to FMT and psychiatric illnesses. All results were then evaluated based on specific eligibility criteria.

Results: Twenty-one studies met the eligibility criteria and were analysed for reported changes in mood and behavioural measures indicative of psychiatric wellbeing. The studies included were either entirely clinical $(n=8)$, preclinical with human donors $(n=9)$, or entirely preclinical $(n=11)$. All studies found a decrease in depressive and anxiety-like symptoms and behaviours resulting from the transplantation of healthy microbiota. The inverse was also found, with the transmission of depressive and anxiety-like symptoms and behaviours resulting from the transplantation of microbiota from psychiatrically ill donors to healthy recipients.

Conclusion: There appears to be strong evidence for the treatment and transmission of psychiatric illnesses through FMT. Further research with larger sample sizes and stronger scientific design is warranted in order to fully determine the efficacy and safety of this potential treatment. Registered on PROSPERO, IRD: CRD42019126795.
\end{abstract}

Keywords: Fecal microbiota transplant, Gut-brain axis, Psychiatric illness, Depression, Anxiety, Eating disorders, Substance abuse, Chronic stress

\footnotetext{
* Correspondence: 14acm@queensu.ca

${ }^{1}$ Department of Psychiatry, Queen's University, 752 King St. West, Kingston, ON K7L 4X3, Canada

${ }^{2}$ Providence Care Hospital, 752 King St. West, Kingston, ON K7L 4X3, Canada

Full list of author information is available at the end of the article
}

\section{$\triangle B M C$}

(c) The Author(s). 2020 Open Access This article is licensed under a Creative Commons Attribution 4.0 International License, which permits use, sharing, adaptation, distribution and reproduction in any medium or format, as long as you give appropriate credit to the original author(s) and the source, provide a link to the Creative Commons licence, and indicate if changes were made. The images or other third party material in this article are included in the article's Creative Commons licence, unless indicated otherwise in a credit line to the material. If material is not included in the article's Creative Commons licence and your intended use is not permitted by statutory regulation or exceeds the permitted use, you will need to obtain permission directly from the copyright holder. To view a copy of this licence, visit http://creativecommons.org/licenses/by/4.0/ The Creative Commons Public Domain Dedication waiver (http://creativecommons.org/publicdomain/zero/1.0/) applies to the data made available in this article, unless otherwise stated in a credit line to the data. 


\section{Background}

In recent years, there has been a growing appreciation for research in the field of the "gut-brain axis" (GBA). The GBA consists of bidirectional biochemical and neural signalling between the gastrointestinal (GI) tract and the brain. Specifically, the gut microbiota is able to modulate the GBA both directly and indirectly via endocrine, neural, and immune pathways. In disease- or stress-states these pathways may become compromised resulting in intestinal dysbiosis, changes in mood, behavior, and cognition, and altered inflammatory levels [1].

The gastrointestinal tract is colonized by over one hundred trillion commensal bacteria that exist symbiotically with our bodies. Colonization of the gut occurs at birth and is largely influenced by mode of delivery (c-section vs. vaginal birth) and through breast feeding. However, bacterial composition of the gut begins to stabilize throughout adulthood [2]. Detailed analyses of human gut microbiota have shown considerable individual variability in bacterial content as this dynamic system is influenced by a variety of factors, such as genetics, diet, metabolism, age, geography, antibiotic treatment, psychotropics, and stress [3, 4].

Gut microbiota are critical in the normal development of the immune system, central nervous system (CNS) circuitry, GI functioning, and autonomic nervous system (ANS) functioning. This community of bacteria and its genetic material is often referred to as a virtual organ [4-6]. Studies have since shown that gut bacteria play a vital role in regulating important aspects of brain development and function, along with other host physiology $[5,7]$.

\section{The gut and psychiatric symptoms and disorders}

The interaction of the gut with the environmental risk factors of psychiatric illnesses, such as diet and early life stress, suggests that interventions targeting the gut microbiome could prevent and treat psychiatric symptoms [8]. Psychiatric symptoms can manifest in both psychological and physiological ways, often resulting in impaired functioning. Common physiological symptoms share similarities with symptoms of GI disorders, such as Irritable Bowel Syndrome (IBS). This association may be explained by the close connection between the gut and the brain.

In past studies, individuals with psychiatric illness have also been shown to have a dissimilar microbiota composition compared to healthy individuals, due to decreased diversity and abundance of the healthy gut microbes [9]. Studies also show that lack of exposure to commensal bacteria, such as in germ-free mice, has significant effects on stress responsiveness in adulthood; it has also been shown that early colonization of the gut with a conventional microbiota, even a single species, can partially reverse these effects [10]. Some investigations have shown neurochemical changes as a result of gut microbiome dysfunction, such as altered levels of brain-derived neurotropic factor (BDNF), reduced serotonin receptor expression, reduced synaptic plasticity gene expression, and increased striatal monoamine turnover [10-12].

\section{Fecal microbiota transplant}

Several methods of examining the influence of the gut microbiome on the gut-brain axis have been explored, including manipulating the microbiome via probiotic and antibiotic administration, the use of germ-free animal models, and perhaps most notably, fecal microbiota transplantation (FMT). FMT is the transfer of fecal bacteria from a healthy donor to a recipient. FMT was first used in fourth century China for the treatment of severe food poisoning and diarrhea and other related symptoms [13]. However, it is currently only indicated for the treatment of Clostridium difficile (C. difficile.) infections. $C$. difficile is often contracted by older patients in-hospital following routine pharmacological treatments such as antibiotics. The use of antibiotics often depletes healthy bacteria in the GI tract which can result in microbial dysfunction. FMT is used to restore healthy status of the microbiome via repopulation of healthy bacteria to the gut. Functioning in a similar manner to probiotics, this treatment method helps to maintain the bacterial balance and function. FMT are most commonly accomplished via endoscopies, enemas, and oral feeding of freeze-dried material. Aside from GI and psychiatric disorders, this treatment method is also being explored as a potential treatment for metabolic disorders, autism, multiple sclerosis, and Parkinson's disease [14-17]. Other variations of this treatment, such as Microbial Ecosystem Therapeutics-2 (MET-2) are also currently being explored, in psychiatric indications such as Generalized Anxiety (GAD) and Major Depressive Disorders (MDD). MET-2 consists of gut bacteria obtained from stool samples of a healthy donor, chosen for its safety profile, that is then purified and lab-grown prior to being lyophilized and ingested orally by patients [18].

\section{FMT in the context of psychiatric illness}

Two of the most prevalent groups of psychiatric disorders include Major Depressive Disorder and anxiety disorders. MDD is characterized by either depressed mood and/or loss of interest or pleasure, as well other psychiatric and physiological symptoms. Anxiety disorders is a category that includes a variety of disorders characterized by intense feelings of anxiety, nervousness, or fear. These include Generalized Anxiety Disorder, Agoraphobia, Panic Disorder, and specific phobias. Both groups of disorders are characterized by a significant impairment 
in daily functioning [19]. While there are pharmacological treatments available for both disorders, many people deny treatment due to side effects or stigmarelated reasons or are treatment-resistant and unable to find an effective way to improve their symptoms. By targeting the gut, FMT may be a potential way to overcome these drawbacks. Research on the gut-brain axis indicates that there may be a possibility to improve these symptoms through restoration of the gut microbiome via fecal transplant from a healthy donor. However, as this is a relatively novel area of research, there are few studies on FMT in humans as a treatment method in the context of psychiatric disorders.

This review examines findings from preclinical and clinical studies that have examined the effects of endogenous microbiome transfer on psychiatric symptoms. The studies included in this review assess the effects of FMT and related interventions on symptoms associated with a variety of psychiatric illnesses including MDD, anxiety, and chronic stress. Comorbid disorders associated with poor mental health outcomes such as alcoholism and anorexia were also included in several of the studies.

\section{Methods}

\section{Literature search strategy}

This review adhered to the Preferred Reporting Items for Systematic Reviews and Meta-Analyses (PRISMA) guidelines (Fig. 1, [20]). Relevant studies were identified by systematically searching the following databases: MEDLINE, EMBASE, CINAHL, PsycINFO, and Web of Science using key search terms including: mood, anxiety, mania, stress, phobia, microbiota transfer, and fecal transplant. The strategy adapted to each of the databases listed above and is described in detail in Appendix 1 . Searches were conducted in November 2019 and yielded 285 studies after duplicates were removed. The search was updated in April 2020, yielding 7 new studies after full-text screening. Any studies that were excluded during full-text screening were due to wrong study design or outcomes. Reasons for which articles were rejected on the basis of 'wrong study design' include the article being a review paper or only an abstract. Those that were rejected due to "wrong study outcome" did not measure any clinical symptoms directly related to psychiatric illness.

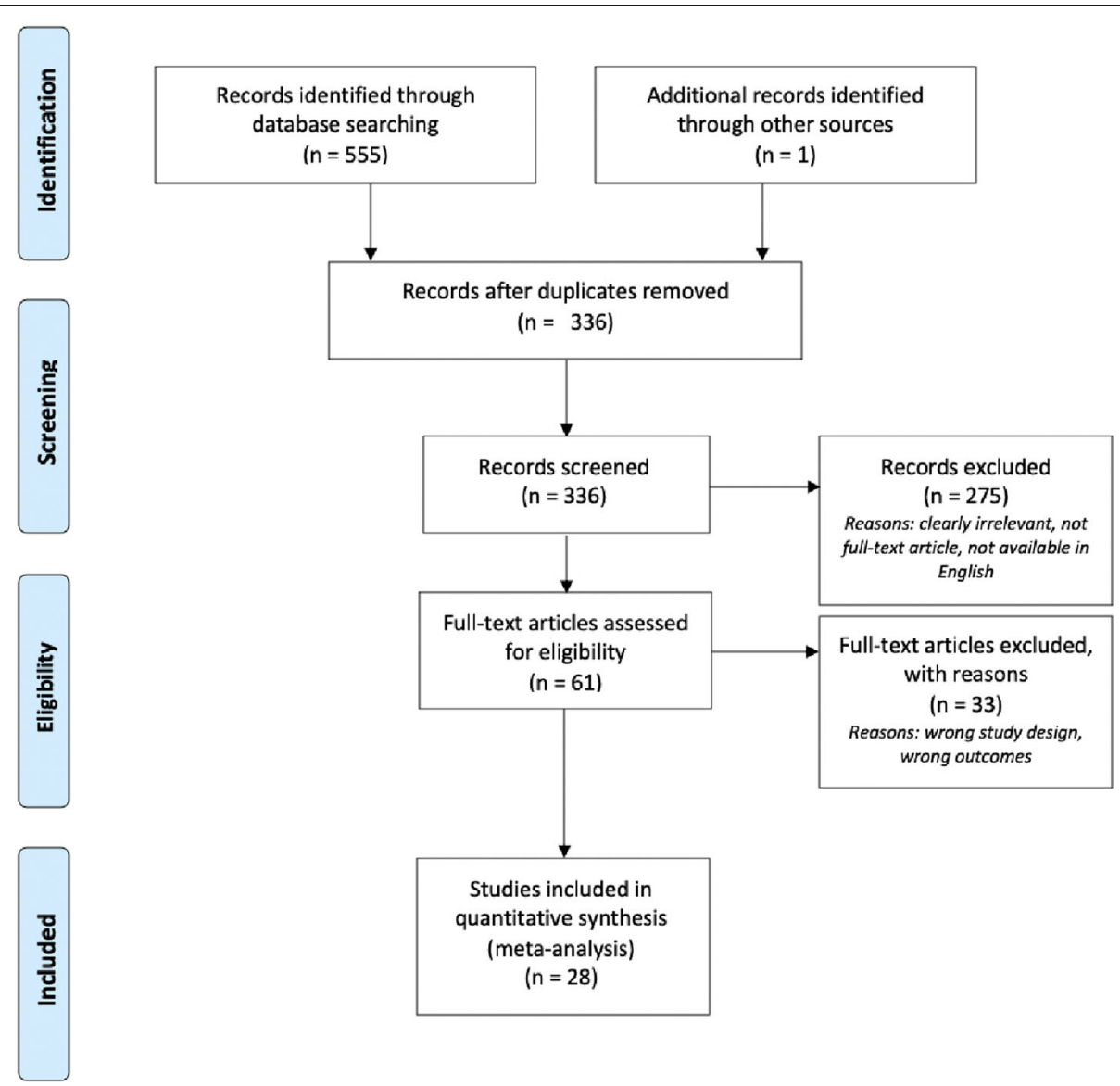

Fig. 1 Flow chart showing literature search and screening process using PRISMA process 


\section{Eligibility criteria}

All articles eligible for inclusion were published in peerreviewed journals and were written in English. The studies were restricted to preclinical or clinical samples that were assessed for changes in symptoms of psychiatric illness after undergoing an endogenous microbe transfer via any route of administration.

\section{Study selection}

One author (A.C.M) completed initial search of the databases, adhering to the search strategy (Appendix 1). Two authors (A.C.M and C.W) independently assessed the titles and abstracts of records retrieved from the systematic search according to the identified inclusion and exclusion criteria and completed the full-text review. Any disagreements were resolved by a third author (R.M).

\section{Study quality}

The Cochrane Handbook for Systematic Reviews of Interventions Risk of Bias Tool (RoBT) addresses 6 specific domains in assessing the quality of randomized controlled trials: sequence generation, allocation concealment, blinding, incomplete outcome data, selective outcome reporting and 'other issues'. All included studies were analyzed according to these domains by A.C.M and C.W. As there is limited research on this topic, studies that did not follow the double-blind, randomized controlled model, were included if they had a comprehensive methodology after thorough analysis by three of the authors (A.C.M., C.W., and R.M.). Overall, the included studies presented with low levels of potential bias save for cases where blinding of either the participant or study team was not performed. For these cases, bias was assessed as high. Detailed assessments can be found in Table 1. Allocation concealment was not assessed since no studies concealed treatment allocation from subjects or participants.

\section{Results}

\section{Study characteristics}

This review contains 28 studies evaluating the effect of fecal microbiota transplants on various psychiatric and physical symptoms. Of these, eleven studies examined exclusively animal samples, nine studies were preclinical subjects with transplanted microbiota from human donors, and eight studies examined exclusively human samples. The characteristics of these studies are displayed in Tables 2, 3, and 4. The average sample size was $n=23$ for entirely preclinical studies, and $n=78$ for preclinical studies with human donors, and $n=19$ for clinical studies. Four of the preclinical studies failed to report rodent sample size. The symptoms most frequently studied were that of Irritable Bowel Syndrome (IBS), chronic stress, and depressive-like symptoms.

\section{Preclinical studies}

In the eleven preclinical studies included in this review (Table 2), the primary indications investigated were chronic stress $(n=6)$, alcoholism $(n=2)$, chronic neuropathic pain $(n=2)$, and depression $(n=1)$. Of the studies assessing chronic stress, three investigated the effects of FMT from mice subjected to the chronic unpredictable mild stress (CUMS) procedure to healthy mice, one replicated this using the social defeat model of stress in rats, one investigated the effects of fecal transplant from healthy mice to stressed mice, and one investigated the effects of FMT from NLPR3 knockout mice on the resiliency of mice subjected to the CUMS procedure after fecal transplant. When investigating the effects of FMT from CUMS mice to germ free mice, three studies found that the FMT resulted in increased anxiety and depression-like behaviour [21-23]. Mice were assessed using the open-field, tail suspension, forced swimming, and elevated plus maze tests - all standard tests for evaluating symptoms related to stress and depression in the field of depression research in mice. Pearson-Leary et al. conducted a similar study, by using the social defeat rodent model of stress. Male rodents were introduced into cages with retired male breeder rats that were preselected for aggression. This creates a situation where the experimental rats are subjected to several episodes of social defeat by the older, aggressive rats, leading to chronic stress. These rats were then identified as SL/vulnerable (exhibiting passive behaviours and short-latencies to defeat) or LL/resilient (exhibiting active coping behaviours and long-latencies to defeat). SL/vulnerable rats displayed increased depressive and anxiety-like behaviours, whereas LL/resilient rats did not. Naïve rats then received FMT from SL/vulnerable, LL/resilient, or control rats. It was found that rats receiving FMT from the SL/vulnerable group displayed depressive-like behaviours when asses with the forced swim test while the LL/resilient group was not significantly different than control [24].

Langgartner et al. investigated the alleviating properties of FMT by designing a study in which mice were split into chronic subordinate colony housing (CSC) and nonstressful single housing (SHC). CSC housing is a validated way to subject mice to chronic psychological stress, similar to the CUMS procedure. The researchers then evaluated if frequent FMT from SHC to CSC mice could stop the development of anxiety and depression-like symptoms. It was found that these transplants were mildly stress protective, resulting in decreased anxiety and depression-like symptoms in the recipient mice [25]. Zhang et al. also investigated the protective properties of FMT by transplanting the microbiota from NLPR3 knockout mice into GF mice. NLPR3 is a gene involved in the aforementioned immune pathway that modulates the GBA. The transcripts of this gene have been found to be increased in both patients with depression and mouse models for depression [26, 27]. 
Knocking out this gene is thought to be protective against the development of depressive-like symptoms in mice. These mice were then subjected to the CUMS procedure in order to see the effects of the FMT on their resiliency. It was found that FMT from NLPR3 knockout mice resulted in a decrease in anxiety and depressive-like behaviours in the recipient mice [28].

Xiao et al. evaluated the transfer of alcohol-withdrawal symptoms via FMT. In this study, the donor mice were treated with alcohol - they were forced to ingest alcohol for 2 weeks, with the concentration of alcohol increasing from 5 to $35 \%$ over that time period. The fecal microbiota of these mice was then transplanted into healthy control mice. This transplantation resulted in depressive behaviour in the recipient mice. This behaviour was evaluated using the forced swim and tail suspension tests [29]. Jiang et al. conducted a similar study treating mice with alcohol and transplanting their microbiota into germ free mice, but some alcohol treated mice were treated with nicotinamide riboside afterwards. Similar results were found after FMT from alcohol treated mice, but treating the donors with nicotinamide riboside before transplantation stopped the transmission of depressive-like behaviours [30]. Additionally, Tillmann et al. also studied the use of FMT to transfer depressive behaviour, using a Flinders sensitive line (FSL) and Flinders resistant line (FRL) rats. FSL and FRL rats have been widely used for over 30 years as a depression model in rats [31], where FSL rats display depressive-like behaviours, and FRL rats are resistant to the development of depressive-like behaviours. Tillman et al. Investigated the effects of FMT from FSL and FRL rats to FSL, FRL and saline control groups. The only significant behavioural results found were an increased immobility in the forced swim test and decreased time spent in the centre of the open field test resulting from FMT from FSL to control rats, and that rats receiving FRL feces struggled less in the forced swim test than those receiving saline [32]. The former suggests the transfer of depression symptoms from FSL rats to others, and the latter provides evidence against the transference of resiliency from FRL rats. Yang et al. measured pain and depression symptoms in mice after FMT from rats with neuropathic pain presenting with and without anhedonia. Rats were administered a spinal neuropathic injury (SNI) and then assessed for anhedonia susceptibility. After being separated into anhedonia-susceptible and resilient groups, the rats' microbiota was then transplanted into mice, and the mice were assessed for pain responses and depression-like symptoms. It was found that transplants from anhedonia susceptible rats aggravated pain and depression-like symptoms, and those receiving from anhedonia resilient microbiotas had improved pain and depression-like symptoms. The reverse was conducted by Schmidt et al. 2020, investigating the the effects of FMT from healthy rats to rats given a spinal cord injury (SCI) [33]. It was found that the transplantation of a health microbiota resulted in a reduction of anxiety and depressive-like symptoms in mice subjected to SCI, as measured by the elevated plus maze and light-dark tests.

\section{Preclinical studies with human donors}

Of the nine preclinical studies performing FMT from human donors to germ free (GF) mice (Table 3), four assessed the effects of FMT from patients with depression, one from patients with alcoholism, one from patients with anorexia and one from patients with IBS. Two studies assessed the ameliorating properties with the transfer of gut microbiome from healthy human controls to mouse models of alcoholism and autism spectrum disorder respectively. These mice were then assessed for changes in various tests used to indicate change in psychiatric state.

After FMT from individuals with depression to GF mice, three studies found a decrease in centre motion in the open field test [34-36]. Two studies also found a significant increase in immobility duration in the tail suspension and forced swim tests [35, 36]. Liu et al. found increase in immobility duration in the forced swim test only [37]. Although Kelly et al. did not find any changes in the forced swim test, they found a decrease in the total visits to the open arms in the elevated plus maze [34]. These four studies all support that FMT from patients with depression to GF mice can result in depression-like behaviour in the recipient mice.

Alcoholism is highly comorbid with mood and anxiety disorders, with someone with alcoholism being 3.6 and 2.6 times more likely to have a mood or anxiety disorder respectively [38]. In the studies investigating the effect of FMT on depressive and anxiety-like behaviors related to alcoholism, Zhao et al. found that transplants from patients with alcoholism to GF mice resulted in depression and anxiety-like behaviours in the aforementioned tests [39]. The inverse was conducted by $\mathrm{Xu}$ et al. - in their study, mice were treated with alcohol and as a result these mice displayed depression and anxiety-like symptoms in the same tests. FMT was then performed from healthy human donors at different time points throughout the alcohol treatment. $\mathrm{Xu}$ et al. found that when administering 3 FMTs per week, if the transplants began before or during the alcohol treatment, the depression and anxiety-like behaviours were not observed [40]. Chen et al. conducted a similar study investigating the positive effects of FMT from healthy humans to mice models for autism spectrum disorder. The mice either received a transplant from the original pooled human gut microbiome, or from cultured bacteria from the original pooled human microbiome. It was found that both the in vitro cultured and non-cultured bacteria 
transplants resulted in anxiety-like behaviours assessed through the marble burying and self-grooming tests, but that only the non-cultured bacteria transplants resulted improved performance during the open field test.

Anorexia is also closely tied to mood and anxiety disorders, with the likelihood of someone with anorexia having a comorbid mood or anxiety disorder being 2.4 and 1.9 times higher respectively than the general public [41]. When assessing the effects of FMT from patients with anorexia to germ free mice, Hata et al. observed an increase in compulsive and anxiety-like behaviours in the mice when assessed using the open field and marble burying test. As previously seen, the mice spent significantly less time in the centre of the open field test, suggesting anxiety-like behaviour. The mice also buried more marbles than control mice, suggesting compulsive behaviour. The mice also buried more marbles than control mice, suggesting compulsive behaviour [42]. These findings are also consistent in De Palma et al.'s study where transfer of anxiety and IBS symptoms to GF mice via FMT was assessed. In their study, it was found that transplants from anxious IBS donors resulted in more anxiety-like behaviour in recipient mice. This was not the same for transplants from IBS donors without anxiety [43]. These studies all show that FMT can confer certain traits of the donor's psychiatric illnesses to the recipient mouse, and that transplants from healthy donors may be able to alleviate some psychiatric symptom.

\section{Clinical studies}

In contrast to the preclinical studies with human donors, where transplants were primarily from ill and healthy humans into GF mice, in clinical studies (Table 4), the fecal microbiota of healthy volunteers were transplanted into humans with illnesses such as IBS and depression. All eight clinical studies assessed for psychiatric symptoms - six studies assessed depressive symptoms, four assessed anxiety symptoms, one assessed neuroticism, two assessed quality of life in relation to IBS, and one assessed fatigue. Depression symptoms were assessed in four of the six clinical studies using the Hamilton Depression Rating Scale (HAM-D). Other scales used to assess depression symptoms were the Patient Health Questionnaire (PHQ-9), the Quick Inventory of Depressive Symptomatology (QIDS) and the Hospital Anxiety and Depression Scale, depressive sub-scale (HADS-D). All of these studies found a significant short-term improvement in depression symptoms. The long-term effects were less consistent, with three studies finding a return to baseline at week 12, week 20, and month 6 respectively [44-46]. Xie et al., however, found a persistent decrease in depression symptoms lasting up to 17 months after the final round of FMT [47].
Of the four studies assessing anxiety symptoms, three used the Hamilton Anxiety Rating Scale (HAM-A), and one used the Hospital Anxiety and Depression Scale, anxiety sub-scale (HADS-A). Three of the four studies found a significant improvement in anxiety symptoms following FMT [44, 45, 48]. Although Mizuno et al. found improvement in the anxiety scores as well, it was not significant [44]. As with depression symptoms, Huang et al. found the anxiety scores to return to baseline within 6 months post-transplant and Mazzawi et al. found the improvement to be insignificant by week 20 (Huang et al. 2019 [45]; Mazzawi et al. 2018 [46]).

Neuroticism was assessed using the Eynsek Personality Questionnaire-Neuroticism (EPQ-N-12) by Mazzawi et al. A significant decrease in EPQ-N-12 scores was seen at week 3 , but this returned to baseline by week 20 [46]. Huang et al. and Johnsen et al. assessed quality of life using the IBS-QOL scale. Scores on this questionnaire followed a similar pattern as the assessments above, with a significant improvement being observed during the first 3 to 6 months and returning to baseline after 6 to 12 months $[45,49]$. Johnsen et al. also found a similar effect on fatigue, with improvement up to 6 months after FMT and a waning effect from 6 to 12 months [49].

\section{Discussion}

The findings from reviewing the included studies suggest that FMT can affect symptoms of psychiatric disorders. This was shown for both the relief of psychiatric symptoms resulting from the transfer of microbiota from healthy donors to ill recipients and the transmission of symptoms through the transplantation of microbiota from ill donors to healthy recipients. This relationship was investigated in a variety of psychiatric disorders including depression, anxiety, anorexia and alcoholism. The transmissible properties of FMT were also well demonstrated in these studies. Notably, regardless of donor species, the transmission of psychiatric symptoms from ill donors to GF mice was consistently found. This was supported in multiple studies, with observed transference of symptoms from mouse models of depression, anxiety, chronic stress and alcoholism, and from humans with depression, to GF mice. This provides support for the concept that the gut microbiome may both contribute to the development of psychiatric disorders and be a viable target for treatment for these disorders.

All included clinical studies found improvement in the symptoms of psychiatric disorders related to these disorders following FMT from healthy donors. The beneficial aspect of FMT from healthy donors was also demonstrated preclinically where healthy transplants resulted in alleviation of depression- and anxiety-like symptoms that appeared in mice subjected to certain conditions. This alleviation of symptoms was found in mice experiencing alcohol 
withdrawal, as well as stressful living conditions. Though symptom alleviation was consistently observed, the duration of improvement was inconsistent. Some studies, such as Xie et al., observed an alleviation of symptoms that seemed to last indefinitely, but the majority found this to be transient (Xie et al. 2019 [45]; H. L. Huang et al. 2019 [46]; Mazzawi et al. 2018 [44]; Mizuno et al. 2017 [47]). The benefits seemed to last for only around 3-6 months, which, if used as a treatment for psychiatric disorders, is a limitation for FMT in clinical practice.

\section{Mechanism of action}

The mechanism of action for how this gut microbiome modulation results in the observed symptomatic changes has yet to be fully understood. There are currently a few major hypotheses for how the microbiome affects the nervous system, resulting in symptomatic changes. The papers included in this study discussed some of these theories, with the majority postulating the mechanism to be through changes in serotonin production, immune response, and metabolism in response to microbiome changes. Serotonin transmission has long been known to be altered in depression, with selective serotonin reuptake inhibitors (SSRIs) being the most prescribed treatment for depression [50]. An estimated $90 \%$ of the body's serotonin is produced by enterochromaffin (EC) cells in the digestive tract [51]. The functioning of these cells has been known to be affected by gut microbiome changes. One way that microbiome disruption is thought to affect serotonin production is through short chain fatty acids (SCFAs). SCFAs are produced by the gut microbiome through the fermentation of non-digestible carbohydrates, suggesting that treatments that ameliorate gut health can influence SCFA concentrations. SCFAs, particularly butyrate and propionateinfluence the synthesis of the rate limiting enzyme tryptophan hydroxylase which synthesizes serotonin produced by EC cells $[52,53]$. In addition to their role in serotonin production, SCFAs also have the ability to cross gut-blood and blood-brain barriers during immune signaling. The immune system can be affected by the gut simply by the fact that there are many immune cells located in the gastrointestinal tract, meaning that gut disruption can also disrupt these cells. The SCFAs produced by the gut microbiome have anti-inflammatory properties and can work to regulate the immune response [54]. In the gut, they influence expression of antiinflammatory markers, such as interleukin (IL-)10 in macrophages and intestinal dendritic cells [55]. In the central nervous system, SCFAs have additional roles, such as regulating maturity and function of microglia (macrophages in the brain that are part of the brain's immune response) [56]. Many psychiatric disorders have been linked to inflammation and an increased immune response, as observed through elevated levels of immune marker cytokines [57]. It is hypothesised that this response is mediated by the NLRP3 inflammasome, a multiprotein intracellular complex that activates pro-inflammatory cytokines [58].

A more direct way that the microbiota influences the central nervous system is through interaction with the vagus nerve. The vagus nerve is comprised of $80 \%$ afferent nerve fibers and 20\% efferent fibers. Afferent nerve fibers of the vagus nerve are affected by metabolites of the microbiota that then take that information back to central nervous system [59]. This is hypothesized to influence central and peripheral changes resulting in alleviation of psychiatric symptoms. More specifically, the vagus nerve is affected by long and short chain fatty acids both directly and indirectly, through cellular production of neurotransmitters, such as serotonin [60].

These mechanisms may provide insight into the use of FMT as a potential treatment for psychiatric symptoms, such as mood and anxiety. The repopulation of the gut microbiome with healthy bacteria through FMT may have positive neurological, immune, and metabolic effects which in turn may influence the trajectory of the psychiatric indication.

\section{Treatment feasibility}

Using FMT as a treatment for psychiatric illnesses in the future is an interesting idea that merits exploration. MDD and anxiety disorders affect millions of people worldwide and have a very large burden to the individual and society as a whole. The current gold-standard treatment for psychiatric illnesses, MDD and anxiety disorders in particular, are antidepressants medications. Though antidepressants have a relatively high efficacy, a large proportion of individuals with psychiatric illnesses do not respond to these first-line treatments, and thus need to try alternatives [61]. Further, many antidepressant users also experience side effects such as restlessness, nausea, vomiting, anxiety, insomnia, sexual dysfunction, gastrointestinal cramps and diarrhea, and headaches that can make the arduous process of searching for effective treatments even harder [62]. Antidepressant medications are also still steeped in stigma further impeding one's ability to ask for and receive help and treatment. Finally, as is stands, on average antidepressants can be costly, especially without insurance or government-funded healthcare.

There is a great need for new therapeutic targets and treatments in order to provide options and better help individuals suffering from these psychiatric illnesses. When considering the findings demonstrated in this review, FMT appears to be a promising candidate for this. The ongoing research certainly suggests its efficacy and given the few side effects and adverse events reported in these papers, may even challenge the treatments currently available. Though the treatment effect seems 
transient, symptoms appeared to improve relatively quickly after treatment. Another common issue seen in these indications are often to do with treatment adherence. However, given FMT effects can last up to 6 months, it may be easier to adhere to than a daily medication or a weekly psychotherapy appointment. Assuming one transplant is sufficient for therapeutic benefits lasting up to 6 months, the cost of treatment may be comparable to that of brand-name antidepressants, however not much is known about the costs of FMT (Eisenberg Centre at Oregon Health \& Sciences University, 2007). There is potential, however, for cost of FMT to decrease, as treatment becomes more mainstream and modified.

Though the effectiveness and tolerability of FMT, as seen in these studies, makes it a promising potential treatment, there are some aspects that could limit its adoption into mainstream clinical settings. A potential drawback currently is the procedure itself. Although costs are comparable to antidepressants, it is still relatively expensive and a labor-intensive alternative to other psychiatric treatments. Additionally, the safety of FMT has also not been sufficiently understood and its associated stigma is still unknown. These points, along with the treatment still being in the early stages of research, make it difficult to fully determine the feasibility of FMT as a treatment for psychiatric illnesses such as depression and anxiety.

\section{Limitations}

Although the studies included in this review were of good quality and contributed to a greater understanding of FMT in the context of mental health and illness, there are considerable limitations. A significant limitation in any FMT study is the fact that although research on the gut microbiome has been prolific, we still do not know what a healthy microbiome' is. Some researchers refer to a healthy microbiome as one of an individual with no overt diseases and others, however, even among those who are considered healthy, the variation in taxonomic composition is great [63-65].

The main limitation of the clinical studies were small sample sizes. The lack of large-scale, double blind randomized controlled trails makes it difficult to determine efficacy and safety. The majority of clinical studies also assessed the psychiatric symptoms in individuals with IBS, and not necessarily those exclusively with psychiatric disorders. This means that, though there was clear improvement if psychiatric symptoms, it cannot conclusively be said that FMT will improve the symptoms of individuals with psychiatric disorders. Additionally, it is possible that the improvement of psychiatric symptoms is secondary to the improvement of gastrointestinal symptoms associated with IBS, thus is not a direct relationship.

For the preclinical studies using human donors, the sex of the mice and donors was a major limitation, given most studies used donors or mice of only male sex. Given that there are clear sex and gender differences in the prevalence and symptomatology of mental illnesses, further research is warranted to determine if sex and gender have an effect on the efficacy of FMT procedures. Some of these studies also included donors that were taking various medications, including antidepressants, which may have affected the results. Additionally, the administration of antibiotics to create GF recipient mice and the variability in FMT administration protocol make the findings difficult to translate. For instance, some recipients received multiple FMTs, while others received only one and the justification for choosing donors varied. The heterogeneity of indications studied also creates difficulty in knowing, with any certainty, how efficacious this procedure will be for a given indication. Without a consensus on a standard procedure for conducting this research, it is difficult to compare results between studies.

\section{Conclusion}

With high individual variability in symptomatology and prognosis, high levels of comorbidity with other disorders, genetic and environmental influences, progress in research in treatment of psychiatric disorders has been challenging. Given the huge heterogeneity of psychiatric disorders, finding treatment that works for all patients is not achievable, especially given the range of factors that influence the disorder and treatment response. While the research in this field is far from complete, the potential of targeting the gutbrain axis using FMT to alleviate symptoms of psychiatric illness is promising. Additionally, given the adaptable nature of the gut microbiome, it may be a good representation of the individual's history and could explain differences in risk of illness, disease course, and response to treatment. If these therapies are able to alleviate symptoms of psychiatric disorders, they could be offered to some patients as personalized, alternative, and/or adjunctive treatments to combat specific symptoms that tie together specific gut bacteria strains or the gut, as a whole, to the brain.

\section{Appendix \\ Appendix 1. Search Strategy}

1. Depression OR Mood OR Stress, Psychological OR Anxiety OR Mania OR Panic OR Phobia OR Psychiatric illness

2. Microbiota Transplant OR Stool transplant OR Bacteriotherapy OR Microbial Ecosystem Therapy OR Microbial/Microbe Therapy

3. 1 AND 2
a. MEDLINE: 206 Results
b. OVID PsycINFO: 15 Results
c. EMBASE, 206 Results
d. Web of Science, 111 Results
e. CINAHL: 1 Result 


\section{Appendix 2}

Table 1 Quality assessment details

\begin{tabular}{|c|c|c|c|c|c|c|c|c|}
\hline \multirow[t]{2}{*}{ Study } & \multicolumn{2}{|c|}{$\begin{array}{l}\text { Blinding of outcome assessors for all } \\
\text { outcomes }\end{array}$} & \multicolumn{2}{|c|}{$\begin{array}{l}\text { Blinding of participants and } \\
\text { personnel for all outcomes }\end{array}$} & \multirow{2}{*}{$\begin{array}{l}\text { Incomplete } \\
\text { outcome data } \\
\text { for all outcomes } \\
\text { Judgement }\end{array}$} & \multirow{2}{*}{$\begin{array}{l}\text { Selective } \\
\text { outcome } \\
\text { reporting } \\
\text { Judgement }\end{array}$} & \multicolumn{2}{|c|}{ Sequence generation } \\
\hline & Judgement & Comments & Judgement & Comments & & & Judgement & Comments \\
\hline $\begin{array}{l}\text { Cai } 2019 \\
{[66]}\end{array}$ & High & $\begin{array}{l}\text { Single outcome group, no } \\
\text { blinding of any parties } \\
\text { involved }\end{array}$ & High & $\begin{array}{l}\text { Single case, no } \\
\text { blinding of any } \\
\text { parties involved. }\end{array}$ & Unclear & Unclear & High & $\begin{array}{l}\text { Single case, } \\
\text { no sequence } \\
\text { generation }\end{array}$ \\
\hline $\begin{array}{l}\text { Tillmann } \\
2019[32]\end{array}$ & Low & & & & Low & Low & & \\
\hline $\begin{array}{l}\text { Kurokawa } \\
2018[48]\end{array}$ & High & $\begin{array}{l}\text { Outcome assessors not } \\
\text { blinded. }\end{array}$ & High & $\begin{array}{l}\text { Participants and } \\
\text { personnel not } \\
\text { blinded. }\end{array}$ & Low & Low & & \\
\hline $\begin{array}{l}\text { DePalma } \\
2017[43]\end{array}$ & High & $\begin{array}{l}\text { Investigators not blinded for } \\
\text { behavioural and } \\
\text { gastrointestinal motility } \\
\text { tests. }\end{array}$ & Low & & Low & Low & Low & \\
\hline $\begin{array}{l}\text { Xiao } 2018 \\
{[29]}\end{array}$ & Low & & Low & & Low & Low & Low & \\
\hline $\begin{array}{l}\text { Mazzawi } \\
2018[46]\end{array}$ & High & $\begin{array}{l}\text { Outcomes assessors not } \\
\text { blinded. }\end{array}$ & High & $\begin{array}{l}\text { Participants and } \\
\text { personnel not } \\
\text { blinded. }\end{array}$ & Low & Low & Low & \\
\hline Xu 2018 [40] & Low & & Low & & Low & Low & Unclear & \\
\hline $\begin{array}{l}\text { deClercq } \\
2019[67]\end{array}$ & High & & High & & Unclear & Unclear & High & \\
\hline $\begin{array}{l}\text { Huang } 2019 \\
\text { [36] }\end{array}$ & Low & & Low & & Low & Low & Unclear & \\
\hline $\begin{array}{l}\text { Huang } 2019 \\
{[45]}\end{array}$ & High & $\begin{array}{l}\text { Outcomes assessors not } \\
\text { blinded. }\end{array}$ & High & $\begin{array}{l}\text { Participants and } \\
\text { personnel not } \\
\text { blinded. }\end{array}$ & Low & Low & & \\
\hline Li 2019 [21] & Unclear & & Unclear & & Low & Low & Low & \\
\hline $\begin{array}{l}\text { Zhang } 2019 \\
{[28]}\end{array}$ & Low & & Low & & Low & Low & Unclear & \\
\hline $\begin{array}{l}\text { Xie } 2019 \\
{[47]}\end{array}$ & High & $\begin{array}{l}\text { Outcome assessors not } \\
\text { blinded. }\end{array}$ & High & $\begin{array}{l}\text { Participant and } \\
\text { personnel not } \\
\text { blinded. }\end{array}$ & Low & Low & & \\
\hline $\begin{array}{l}\text { Zhao } 2019 \\
\text { [39] }\end{array}$ & Low & & Low & & Low & Low & Low & \\
\hline $\begin{array}{l}\text { Kelly } 2016 \\
{[34]}\end{array}$ & Unclear & & Unclear & & Low & Low & Low & \\
\hline $\begin{array}{l}\text { Mizuno } \\
2017[44]\end{array}$ & Low & & High & $\begin{array}{l}\text { Participants and } \\
\text { personnel not } \\
\text { blinded. }\end{array}$ & Low & Low & & \\
\hline $\begin{array}{l}\text { Langgartner } \\
2018 \text { [25] }\end{array}$ & High & $\begin{array}{l}\text { Outcome assessors, aside } \\
\text { from histological scoring, } \\
\text { were not blinded. }\end{array}$ & High & $\begin{array}{l}\text { Personnel not } \\
\text { blinded. }\end{array}$ & Low & Low & Low & \\
\hline $\begin{array}{l}\text { Yang } 2019 \\
{[68]}\end{array}$ & Unclear & & Unclear & & Low & Low & Low & \\
\hline $\begin{array}{l}\text { Hata } 2019 \\
{[42]}\end{array}$ & Unclear & & Unclear & & Low & Low & Unclear & \\
\hline Lv 2019 [22] & Unclear & & Unclear & & Low & Low & Low & \\
\hline Zheng 2016 & Low & & Low & & Low & Low & Low & \\
\hline
\end{tabular}


Table 1 Quality assessment details (Continued)

\begin{tabular}{|c|c|c|c|c|c|c|c|c|}
\hline \multirow[t]{2}{*}{ Study } & \multicolumn{2}{|c|}{$\begin{array}{l}\text { Blinding of outcome assessors for all } \\
\text { outcomes }\end{array}$} & \multicolumn{2}{|c|}{$\begin{array}{l}\text { Blinding of participants and } \\
\text { personnel for all outcomes }\end{array}$} & \multirow{2}{*}{$\begin{array}{l}\text { Incomplete } \\
\text { outcome data } \\
\text { for all outcomes } \\
\text { Judgement }\end{array}$} & \multirow{2}{*}{$\begin{array}{l}\text { Selective } \\
\text { outcome } \\
\text { reporting } \\
\text { Judgement }\end{array}$} & \multicolumn{2}{|c|}{ Sequence generation } \\
\hline & Judgement & Comments & Judgement & Comments & & & Judgement & Comments \\
\hline $\begin{array}{l}\text { Pearson- } \\
\text { Leary } 2019 \\
{[24]}\end{array}$ & Low & & Low & & Low & Low & Low & \\
\hline $\begin{array}{l}\text { Schmidt } \\
2020 \text { [33] }\end{array}$ & Low & & Low & & Low & Low & Low & \\
\hline $\begin{array}{l}\text { Johnsen } \\
2020[49]\end{array}$ & Low & & Low & & Low & Low & Low & \\
\hline $\begin{array}{l}\text { Jiang } 2020 \\
{[30]}\end{array}$ & High & $\begin{array}{l}\text { Outcome assessors not } \\
\text { blinded. }\end{array}$ & Low & & Low & Low & Low & \\
\hline $\begin{array}{l}\text { Chen } 2020 \\
\text { [69] }\end{array}$ & High & $\begin{array}{l}\text { Outcome assessors not } \\
\text { blinded. }\end{array}$ & Low & & Low & Low & Low & \\
\hline $\begin{array}{l}\text { Siopi } 2020 \\
{[23]}\end{array}$ & Low & & Low & & Low & & Low & \\
\hline $\begin{array}{l}\text { Liu } 2020 \\
{[37]}\end{array}$ & High & $\begin{array}{l}\text { Outcome assessors not } \\
\text { blinded. }\end{array}$ & Low & & Low & Low & Low & \\
\hline
\end{tabular}


Table 2 Preclinical studies

\begin{tabular}{|c|c|c|c|c|c|c|}
\hline Study & $\begin{array}{l}\text { Sample } \\
\text { characteristics }\end{array}$ & Study design & Intervention & Donor & Measurement & Key findings and conclusions \\
\hline $\begin{array}{l}\text { Zhang et al. } \\
2019 \text { [28] }\end{array}$ & $\begin{array}{l}\text { Chronic Stress } \\
\text { Mice }\end{array}$ & $\begin{array}{l}\text { Randomized } \\
\text { Controlled } \\
\text { Trial }\end{array}$ & $\begin{array}{l}\text { FMT from wildtype (WT) } \\
\text { and NLRP3 KO mice to } \\
\text { chronic unpredictable } \\
\text { stress (CUS) mice }\end{array}$ & $\begin{array}{l}\text { WT and NLRP3 KO } \\
\text { mice }\end{array}$ & $\begin{array}{l}\text { SPT, FST, TST, } \\
\text { and OFT }\end{array}$ & $\begin{array}{l}\text { - Transplantation of the } \\
\text { NLRP3 KO gut microbiota } \\
\text { ameliorated CUS-induced } \\
\text { depressive-like behaviors. }\end{array}$ \\
\hline $\begin{array}{l}\text { Li et al. } 2019 \\
\text { [21] }\end{array}$ & $\begin{array}{l}\text { Antibiotic } \\
\text { treated } 8 \text { male } \\
\text { WT and } 8 \text { male } \\
\text { chronic } \\
\text { unpredictable } \\
\text { mild stress } \\
\text { (CUMS) mice }\end{array}$ & $\begin{array}{l}\text { Randomized } \\
\text { Controlled } \\
\text { Trial }\end{array}$ & $\begin{array}{l}\text { Oral FMT for } 2 \text { weeks from } \\
\text { WT and CUMS mice to } \\
\text { antibiotic-treated WT and } \\
\text { CUMS mice }\end{array}$ & $\begin{array}{l}8 \text { WT mice and } 8 \\
\text { CUMS mice }\end{array}$ & $\begin{array}{l}\text { SPT, OFT, } \\
\text { EPM, FST }\end{array}$ & $\begin{array}{l}\text { - FMT of CUMS microbiota } \\
\text { induced anxiety-like and } \\
\text { depression-like behavior in } \\
\text { the recipient mice }\end{array}$ \\
\hline $\begin{array}{l}\text { Lv et al. } \\
2019 \text { [22] }\end{array}$ & $\begin{array}{l}\text { Antibiotic } \\
\text { treated Male rats } \\
\text { with and } \\
\text { without CUS }\end{array}$ & $\begin{array}{l}\text { Randomized } \\
\text { Controlled } \\
\text { Trial }\end{array}$ & $\begin{array}{l}\text { 3-day oral FMT from WT } \\
\text { and CUMS mice to } \\
\text { antibiotic-treated rats with } \\
\text { and without CUS }\end{array}$ & $\begin{array}{l}\text { WT and CUMS } \\
\text { mice }\end{array}$ & $\begin{array}{l}\text { SPT, OFT, } \\
\text { EPM, FST }\end{array}$ & $\begin{array}{l}\text { - Transplantation of CUMS } \\
\text { Microbiome Induces } \\
\text { Depression-Like Behaviors } \\
\text { in Antibiotic-Treated Rats as } \\
\text { shown via a decrease in } \\
\text { time spent in the central } \\
\text { area in the OFT and } \\
\text { increased immobility in the } \\
\text { TST }\end{array}$ \\
\hline \multirow[t]{2}{*}{$\begin{array}{l}\text { Xiao et al. } \\
2018 \text { [29] }\end{array}$} & \multirow[t]{2}{*}{$\begin{array}{l}\text { 6-8 week male } \\
\text { C57BL/6 mice }\end{array}$} & \multirow[t]{2}{*}{$\begin{array}{l}\text { Randomized } \\
\text { Controlled } \\
\text { Trial }\end{array}$} & \multirow[t]{2}{*}{$\begin{array}{l}14 \text { days of saline or oral } \\
\text { FMT from alcohol or water } \\
\text { exposed mice to healthy } \\
\text { control mice }\end{array}$} & \multirow[t]{2}{*}{$\begin{array}{l}\text { Alcohol-exposed and } \\
\text { water-exposed mice }\end{array}$} & \multirow[t]{2}{*}{ FST and TST } & $\begin{array}{l}\text { - FMT from alcohol-exposed } \\
\text { mice induced depressive } \\
\text { behavior in the recipients, } \\
\text { shown by significant results } \\
\text { in FST and TST }\end{array}$ \\
\hline & & & & & & $\begin{array}{l}\text { - Alcohol withdrawal } \\
\text { induced symptoms were } \\
\text { transmitted to healthy } \\
\text { controls }\end{array}$ \\
\hline \multirow{4}{*}{$\begin{array}{l}\text { Yang et al. } \\
2019 \text { [68] }\end{array}$} & \multirow{4}{*}{$\begin{array}{l}\text { Antibiotic } \\
\text { treated two- } \\
\text { month-old male } \\
\text { C57BL/6 mice }\end{array}$} & \multirow{4}{*}{$\begin{array}{l}\text { Randomized } \\
\text { Controlled } \\
\text { Trial }\end{array}$} & \multirow{4}{*}{$\begin{array}{l}14 \text { days of FMT from rats to } \\
\text { antibiotic treated C57BL/ } 6 \\
\text { mice }\end{array}$} & Two-month old & \multirow{4}{*}{$\begin{array}{l}\text { Mechanical } \\
\text { withdrawal test } \\
\text { (MWT), Tail flick } \\
\text { test (TFT), SPT, } \\
\text { locomotion, TST, } \\
\text { and FST }\end{array}$} & - Antibiotic administration \\
\hline & & & & \multirow[t]{3}{*}{$\begin{array}{l}\text { Sprague Dawley rats } \\
\text { with and without } \\
\text { anhedonia }\end{array}$} & & $\begin{array}{l}\text { MWT scores, latency of TFT, } \\
\text { and depression-like } \\
\text { behaviors. }\end{array}$ \\
\hline & & & & & & $\begin{array}{l}\text { - FMT from rats with } \\
\text { anhedonia significantly } \\
\text { aggravated behavioral } \\
\text { abnormalities, pain, } \\
\text { depression-like, and } \\
\text { anhedonia-like behaviors in } \\
\text { recipient mice }\end{array}$ \\
\hline & & & & & & $\begin{array}{l}\text { - Antibiotics-treated } \\
\text { pseudogerm-free mice } \\
\text { showed depression-like and } \\
\text { anhedonia-like phenotype } \\
\text { compared to control group, } \\
\text { which were improved by } \\
\text { FMT from mice without } \\
\text { anhedonia. }\end{array}$ \\
\hline \multirow[t]{3}{*}{$\begin{array}{l}\text { Tillmann et } \\
\text { al. } 2019 \text { [32] }\end{array}$} & \multirow[t]{3}{*}{$\begin{array}{l}24 \text { adult male } \\
\text { Flinders sensitive } \\
\text { line (FSL) and } 24 \\
\text { Flinders resistant } \\
\text { line }\end{array}$} & \multirow[t]{3}{*}{$\begin{array}{l}\text { Randomized } \\
\text { Controlled } \\
\text { Trial }\end{array}$} & \multirow[t]{3}{*}{$\begin{array}{l}\text { FMT from } F R L \text {, saline, or } \\
\text { FSL rats to FRL and FSL rats } \\
\text { administered every third } \\
\text { day over a } 16 \text {-day period }\end{array}$} & \multirow[t]{3}{*}{$\begin{array}{l}F S L, F R L \text {, or saline } \\
\text { rats }\end{array}$} & \multirow[t]{3}{*}{ OFT and FST } & $\begin{array}{l}\text { - Rats receiving FRL feces } \\
\text { struggled less than saline- } \\
\text { treated ones while there } \\
\text { was no difference between } \\
\text { FSL feces and saline or FSL } \\
\text { and FRL feces. }\end{array}$ \\
\hline & & & & & & $\begin{array}{l}\text { - Rats receiving FSL feces } \\
\text { had significantly increased } \\
\text { immobility compared with } \\
\text { saline, whereas FRL feces } \\
\text { did not differ from saline. }\end{array}$ \\
\hline & & & & & & $\begin{array}{l}\text { - No difference in immobility } \\
\text { between FSL and FRL feces. }\end{array}$ \\
\hline
\end{tabular}


Table 2 Preclinical studies (Continued)

\begin{tabular}{|c|c|c|c|c|c|c|}
\hline Study & $\begin{array}{l}\text { Sample } \\
\text { characteristics }\end{array}$ & Study design & Intervention & Donor & Measurement & Key findings and conclusions \\
\hline \multirow[t]{2}{*}{$\begin{array}{l}\text { Langgartner } \\
\text { et al. } 2018 \\
{[25]}\end{array}$} & \multirow[t]{2}{*}{$\begin{array}{l}\text { Male C57BL/6 N } \\
\text { chronically } \\
\text { stressed mice via } \\
\text { chronic } \\
\text { subordinate } \\
\text { colony (CSC) }\end{array}$} & \multirow[t]{2}{*}{$\begin{array}{l}\text { Randomized } \\
\text { Controlled } \\
\text { Trial }\end{array}$} & \multirow[t]{2}{*}{$\begin{array}{l}\text { Repeated FMT from non- } \\
\text { stressed single-housed } \\
\text { control (SHC) mice }\end{array}$} & \multirow[t]{2}{*}{$\begin{array}{l}\text { Non-stressed, SHC } \\
\text { Male C57BL/6 N mice }\end{array}$} & \multirow[t]{2}{*}{$\begin{array}{l}\text { OFT and open- } \\
\text { field/novel } \\
\text { object (OF/NO) } \\
\text { test }\end{array}$} & $\begin{array}{l}\text { - SHC feces transplantation } \\
\text { had mild stress-protective } \\
\text { effects as shown by an } \\
\text { improvement of CSC- } \\
\text { induced thymus atrophy, } \\
\text { anxiety, systemic low-grade } \\
\text { inflammation, and } \\
\text { alterations in bone } \\
\text { homeostasis. }\end{array}$ \\
\hline & & & & & & $\begin{array}{l}\text { - CSC feces transplantation } \\
\text { slightly aggravated CSC- } \\
\text { induced systemic low- } \\
\text { grade inflammation and } \\
\text { alterations in bone } \\
\text { homeostasis in SHC and/or } \\
\text { CSC animals. }\end{array}$ \\
\hline \multirow[t]{2}{*}{$\begin{array}{l}\text { Jiang et al. } \\
2020 \text { [30] }\end{array}$} & \multirow[t]{2}{*}{$\begin{array}{l}\text { 18, 7-weeek old, } \\
\text { antibiotic treated } \\
\text { C57BL/6 J mice }\end{array}$} & \multirow[t]{2}{*}{$\begin{array}{l}\text { Randomized } \\
\text { Controlled } \\
\text { Trial }\end{array}$} & \multirow{2}{*}{$\begin{array}{l}\text { FMT from } 6 \text { control, } 6 \\
\text { alcohol-induced } \\
\text { depression, and } 6 \text { alcohol- } \\
\text { induced depression } \\
\text { nicotinamide riboside (NR) } \\
\text { treated mice after } 3 \text { weeks } \\
\text { of antibiotic treatment }\end{array}$} & \multirow{2}{*}{$\begin{array}{l}\text { Control, alcohol- } \\
\text { induced depression } \\
\text { model, and alcohol- } \\
\text { induced depression } \\
\text { model NR-treated } \\
\text { C57BL/6 J mice }\end{array}$} & \multirow[t]{2}{*}{$\begin{array}{l}\text { SPT, FST, EPM, } \\
\text { and Y-Maze }\end{array}$} & $\begin{array}{l}\text { - Mice receiving FMT from } \\
\text { alcohol induced depression } \\
\text { model exhibited } \\
\text { depression-like behaviour }\end{array}$ \\
\hline & & & & & & $\begin{array}{l}\text { - Mice receiving FMT from } \\
\text { control or NR mice did not } \\
\text { exhibit depression-like } \\
\text { behaviour. }\end{array}$ \\
\hline $\begin{array}{l}\text { Schmidt et } \\
\text { al. } 2020 \text { [33] }\end{array}$ & $\begin{array}{l}\text { Adult female } \\
\text { Lewis rats }\end{array}$ & $\begin{array}{l}\text { Randomized } \\
\text { Double-Blind } \\
\text { Sham } \\
\text { Controlled } \\
\text { Trial }\end{array}$ & $\begin{array}{l}\text { FMT from healthy rats is } \\
\text { given to rats with spinal } \\
\text { cord injury }(\mathrm{SCl})\end{array}$ & $\begin{array}{l}\text { Healthy, uninjured, } \\
\text { adult female Lewis } \\
\text { rats }\end{array}$ & $\begin{array}{l}\text { Light-dark box, } \\
\text { Cylinder test, } \\
\text { SPT, EPM, OFT }\end{array}$ & $\begin{array}{l}\text { - FMT from healthy rats } \\
\text { significantly reduced } \\
\text { depression and anxiety-like } \\
\text { behaviour resulting from } \\
\text { SCI in the elevated plus } \\
\text { maze and light-dark box } \\
\text { (significantly more time in } \\
\text { open arms of the maze and } \\
\text { light box) }\end{array}$ \\
\hline $\begin{array}{l}\text { Siopi et al. } \\
2020 \text { [23] }\end{array}$ & $\begin{array}{l}\text { 8-week old, } \\
\text { antibiotic- } \\
\text { treated, GF } \\
\text { C57BL/6 J mice }\end{array}$ & $\begin{array}{l}\text { Randomized } \\
\text { Controlled } \\
\text { Trial }\end{array}$ & $\begin{array}{l}\text { Antibiotic-treated GF mice } \\
\text { receive FMT from } 10 \\
\text { control, or } 10 \text { unpredictable } \\
\text { chronic mild stress (USMS) } \\
\text { mice }\end{array}$ & $\begin{array}{l}\text { Control or UCMS } \\
\text { mice }\end{array}$ & $\begin{array}{l}\text { TST, FST, OFT, } \\
\text { EPM, Light-dark } \\
\text { Box }\end{array}$ & $\begin{array}{l}\text { FMT from UCMS mice } \\
\text { resulted in despair-like } \\
\text { behaviour in the TST and } \\
\text { FST (increased immobility } \\
\text { time in both) }\end{array}$ \\
\hline \multirow[t]{5}{*}{$\begin{array}{l}\text { Pearson- } \\
\text { Leary et al. } \\
2019 \text { [24] }\end{array}$} & \multirow[t]{2}{*}{$\begin{array}{l}\text { Experimental } \\
\text { Intruders: Singly } \\
\text { housed male } \\
\text { Sprague-Dawley } \\
\text { rats }\end{array}$} & & \multirow[t]{5}{*}{$\begin{array}{l}\text { FMT from vulnerable, } \\
\text { resilient, and control rats } \\
\text { delivered via oral gavage to } \\
\text { naïve recipient rats once } \\
\text { daily for } 5 \text { days. }\end{array}$} & \multirow[t]{5}{*}{$\begin{array}{l}\text { SL/vulnerable, LL/ } \\
\text { resilient rats, or } \\
\text { control rats }\end{array}$} & \multirow[t]{5}{*}{ FST and SIT } & $\begin{array}{l}\text { - FMT from SL/vulnerable rats } \\
\text { to naïve, non-stresses rats } \\
\text { promotes some stress } \\
\text { vulnerability }\end{array}$ \\
\hline & & & & & & - No differences in time \\
\hline & \multirow{3}{*}{$\begin{array}{l}\text { Residents: Male } \\
\text { Long-Evans (LE) } \\
\text { retired breeders } \\
(600-800 \mathrm{~g}) \\
\text { were used as } \\
\text { residents. }\end{array}$} & & & & & $\begin{array}{l}\text { spent interacting in SIT } \\
\text { between recipient groups } \\
\text { suggesting no difference in } \\
\text { anxiety-like behavior }\end{array}$ \\
\hline & & & & & & $\begin{array}{l}\text { - Rats treated with vulnerable } \\
\text { microbiota had increased } \\
\text { passive depression-like } \\
\text { behaviours (decreased } \\
\text { latency to immobility, less } \\
\text { time swimming, and } \\
\text { increased time spent } \\
\text { immobile) }\end{array}$ \\
\hline & & & & & & $\begin{array}{l}\text { - SL/vulnerable microbiota } \\
\text { treated rats also spent less } \\
\text { time climbing, but this was } \\
\text { not significant }\end{array}$ \\
\hline
\end{tabular}


Table 3 Preclinical studies with human donors

\begin{tabular}{|c|c|c|c|c|}
\hline Study & $\begin{array}{l}\text { Sample } \\
\text { characteristics }\end{array}$ & Study design & Intervention & Donor \\
\hline $\begin{array}{l}\text { De } \\
\text { Palma } \\
\text { et al. } \\
2019 \\
\text { [43] }\end{array}$ & $\begin{array}{l}141 \text { GF NIH } \\
\text { Swiss Mice }\end{array}$ & $\begin{array}{l}\text { Randomized } \\
\text { Controlled } \\
\text { Trial }\end{array}$ & $\begin{array}{l}\text { FMT from IBS patients } \\
\text { and healthy donors to GF } \\
\text { mice }\end{array}$ & $\begin{array}{l}4 \text { Anxious IBS-D } \\
\text { patients, } 4 \text { non-anxious } \\
\text { IBS-D patients, Mean } \\
\text { age: } 40 \text { years old; } 5 \\
\text { healthy human controls } \\
\text { (HHC), Mean age: } 42 \\
\text { years }\end{array}$ \\
\hline
\end{tabular}

Measurement Key findings and

conclusions

Donors: HAM-A

Recipients: Light-dark preference test and stepdown test years

\begin{tabular}{|c|c|c|c|}
\hline $\begin{array}{l}\text { Hata et } \\
\text { al. } \\
2019 \\
{[42]}\end{array}$ & $\begin{array}{l}\text { Germ-free (GF) } \\
\text { BALB/c mice }\end{array}$ & $\begin{array}{l}\text { Randomized } \\
\text { Controlled } \\
\text { Trial }\end{array}$ & $\begin{array}{l}\text { Oral FMT with and } \\
\text { without pre-treatment } \\
\text { with live Bacteroides } \\
\text { vulgatus to GF mice }\end{array}$ \\
\hline
\end{tabular}

4 AN patients, Mean age: 23 years, $\mathrm{BMI} 13.7$; 4 HHC, Mean age: 25.3 years, BMI 21.6

Donors: DSM diagnosis of AN

Recipients: Open Field and Marble Burying

- FMT from anxious IBSpatients to mice produced anxiety behaviors in mice

- FMT from IBS patients with normal anxiety and from healthy controls to GF mice showed no significant anxious behaviors in GF mice

- Akkermansia was associated with anxiety behaviors in mice

- FMT from AN patients induces anxiety-like and compulsive behaviors in GF recipient mice and impairs body weight gain

- Pre-treatment with B. vulgatus attenuates compulsive behavior Ages 35-40 other day for 13 days to antibiotic treated mice microbiota suppression, 6 weeks old

et al.

2019

[36]
Randomized FMT from MDD patients Controlled and healthy controls to Trial
Huang GF Mice
Patients with and without alcoholism,

Donors: ICD-10 diagnosis of alcoholism

Recipients: Open field test (OFT), alcohol preference test (APT), elevated plus maze test (EMT), tail suspension test (TST), and social interaction test (SIT),

5 MDD patients; 5 HHC

Donor: DSM-IV diagnosis of depression and HAM-D

Recipient: OFT, TST, forced swimming test (FST), buried food pellet test (BFP) and olfaction behavior test (via modified BFP)

$\begin{array}{llll}\text { Kelly et } & \text { Adult, male } & \text { Randomized } & \text { 3-day pooled sample oral } \\ \text { al. } & \text { Sprague } & \text { Controlled } & \text { FMT from MDD patients } \\ \text { 2016 } & \text { Dawley rats } & \text { Trial } & \begin{array}{l}\text { and healthy controls to } \\ \text { [34] }\end{array} \\ \begin{array}{ll}\text { treated with } \\ \text { antibiotic }\end{array} & & \begin{array}{l}\text { antibiotic treated rats, } \\ \text { cocktail for 28 } \\ \text { days }\end{array} & \begin{array}{l}\text { with booster inoculations } \\ \text { given twice per week } \\ \text { throughout the study. }\end{array}\end{array}$

Pooled fecal samples from 3 severely depressed MDD patients; pooled fecal samples from $3 \mathrm{HHC}$ throughout the study.
Donor: Perceived stress scale (PSS), Beck Depression and Beck Anxiety Scales, HAM-D, etc.

Recipients: Sucrose preference test (SPT), OFT, EMT, FST
- FMT from patients with alcoholism induced spontaneous alcohol dependence in mice

- FMT-Alc group exhibited anxiety-like and depression-like behaviors changes and significantly declined social interaction behaviors

- FMT from MDD patients resulted in significantly increased immobility times for the FST and TST

- The center motion distance (OFT) also significantly decreased compared to controls

- The latency for finding the object by depressed mice was significantly longer than that by healthy controls indicating impaired olfaction.

- Rats receiving FMT from MDD patients demonstrated anhedonialike behaviours as shown by a significant decrease in sucrose intake without affecting fluid intake in SPT

- Rats receiving FMT from MDD patients also exhibited anxiety-like behaviours as shown by a significant decrease in 
Table 3 Preclinical studies with human donors (Continued)

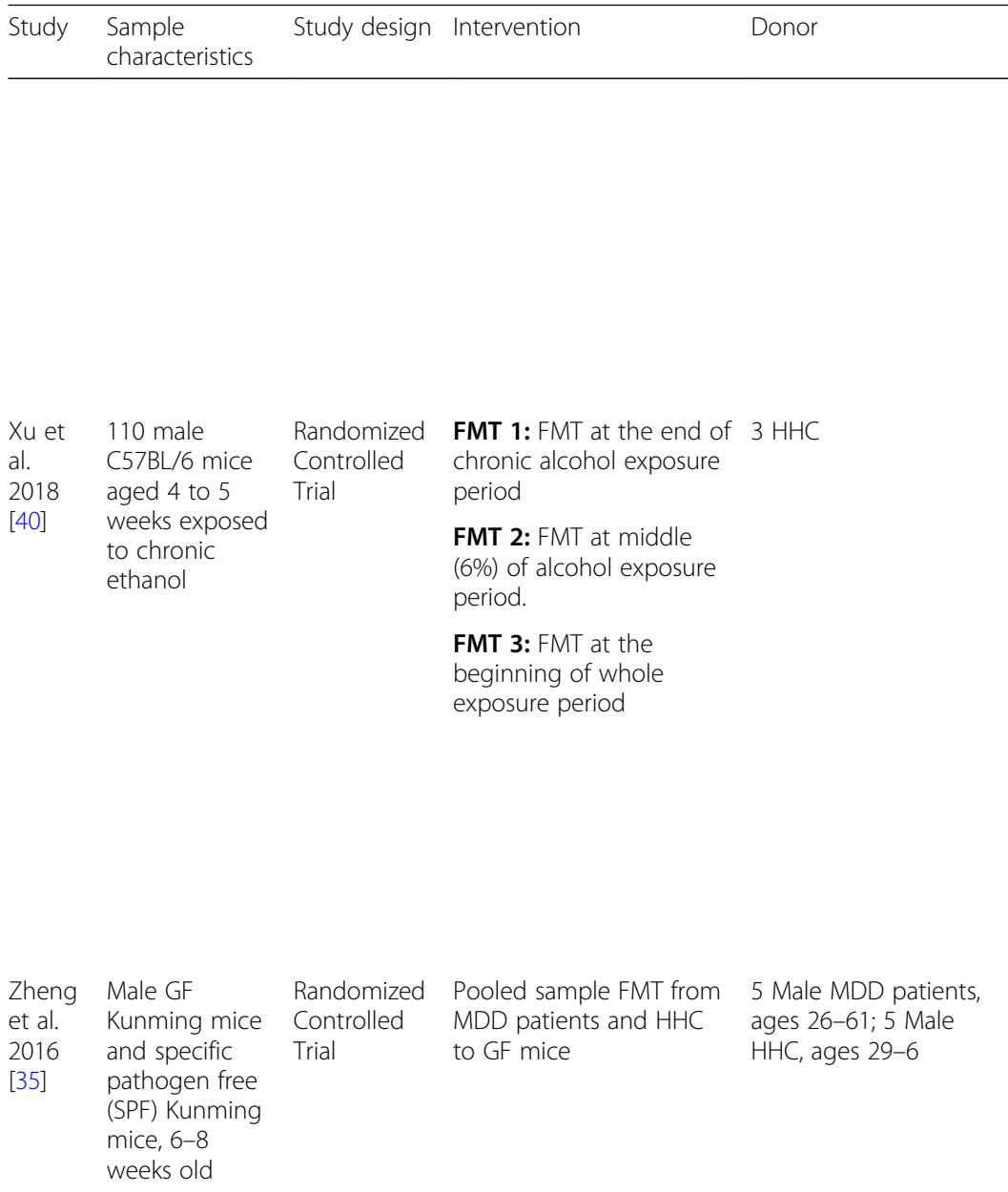

Measurement Key findings and

conclusions

visits to the open arms

in the EMT and a

reduction in time spent

in the centre in the OFT.

- In the forced swim test, there were no significant differences between the groups in immobility time, swimming, or climbing.

Recipients: OFT, TST, FST, • FMT 1 could not and APT alleviate alcohol-induced anxiety or depression.

- FMT 2 alleviated alcoholinduced depression in TST

- FMT 3 modulated anxiety and significantly improved depression.

- FMT 3 decreased Anxiety in OFT and significantly improved depression in TST.

- No significant alcohol preference alternation in FMT-treated mice.

Recipients: OFT, FST, TST A Absence of gut microbiota in germ-free (GF) mice resulted in decreased immobility time in the FST compared to conventionally raised $\mathrm{HC}$ mice

- The gut microbiota compositions of MDD patients and $\mathrm{HC}$ were significantly different with MDD patients characterized by significant changes in the relative abundance of Firmicutes, Actinobacteria and Bacteroidetes.

- FMT from MDD patients to GF mice resulted in depression-like behaviors compared to $\mathrm{HC}$ colonization

- Weight was not significantly different between groups

Original healthy Human OFT, Marble Burying Test, $\cdot \mathbf{M}+\mathrm{O}$ spent bacteria $(M+O)$; in Self-grooming, Threesignificantly more time and had more entries in the OFT, significantly lower $\%$ of marbles burried, and significantly lower \% of gromming time.

$\cdot M+F$ had significantly 
Table 3 Preclinical studies with human donors (Continued)

\begin{tabular}{|c|c|c|c|c|c|c|}
\hline Study & $\begin{array}{l}\text { Sample } \\
\text { characteristics }\end{array}$ & Study design & Intervention & Donor & Measurement & $\begin{array}{l}\text { Key findings and } \\
\text { conclusions }\end{array}$ \\
\hline & & & & & & $\begin{array}{l}\text { lower } \% \text { of marbles } \\
\text { burried, and } \% \text { of } \\
\text { grooming time. }\end{array}$ \\
\hline & & & & & & $\begin{array}{l}\text { - These results suggest } \\
\text { that FMT from organic } \\
\text { in vivo microbiota may } \\
\text { be better at alleviating } \\
\text { depressive and anxiety- } \\
\text { like behaviours, but that } \\
\text { both in vivo snd in vitro } \\
\text { bacteria transplantation } \\
\text { have beneficial } \\
\text { properties. }\end{array}$ \\
\hline \multirow[t]{2}{*}{$\begin{array}{l}\text { Liu et } \\
\text { al. } \\
2020 \\
{[37]}\end{array}$} & $\begin{array}{l}\text { 18, 8-week old } \\
\text { GF rats }\end{array}$ & & $\begin{array}{l}\text { Microbiota from healthy } \\
\text { or depressed humans } \\
\text { were transplanted into GF } \\
\text { mice }\end{array}$ & $\begin{array}{l}\text { Depressed or Healthy } \\
\text { Humans between ages } \\
18-60\end{array}$ & $\begin{array}{l}\text { Donors: } 24+\text { points on } \\
\text { HAM-D, DSM-5 diagnosis } \\
\text { of MDDRecipients: FST, } \\
\text { SPT }\end{array}$ & $\begin{array}{l}\text { - Rats receiving } \\
\text { depression microbiota } \\
\text { exhibited depression-like } \\
\text { behavior (immobility } \\
\text { time in the forced } \\
\text { swimming test was } \\
\text { significantly higher than } \\
\text { in control groups) }\end{array}$ \\
\hline & & & & & & $\begin{array}{l}\text { - From the first week to } \\
\text { the fourth week, the } \\
\text { saccharine preference } \\
\text { index was significantly } \\
\text { lower in the depression } \\
\text { micro- biota group than } \\
\text { that in the blank control } \\
\text { and healthy microbiota } \\
\text { groups }\end{array}$ \\
\hline
\end{tabular}


Table 4 Clinical studies

\begin{tabular}{|c|c|c|c|c|c|c|}
\hline Study & $\begin{array}{l}\text { Sample } \\
\text { characteristics }\end{array}$ & Study design & Intervention & Donor & Measurement & Key findings and conclusions \\
\hline \multirow[t]{2}{*}{$\begin{array}{l}\text { Cai et al. } \\
2019[66]\end{array}$} & \multirow{2}{*}{$\begin{array}{l}1 \text { female MDD } \\
\text { patient, } 79 \\
\text { years old }\end{array}$} & \multirow{2}{*}{$\begin{array}{l}\text { Pre- and post- } \\
\text { intervention } \\
\text { assessment }\end{array}$} & \multirow[t]{2}{*}{$\begin{array}{l}\text { Single time FMT via } \\
\text { gastroscope }\end{array}$} & \multirow[t]{2}{*}{$\begin{array}{l}6 \text { year-old } \\
\text { grandson }\end{array}$} & \multirow[t]{2}{*}{ PHQ-9 } & $\begin{array}{l}\text { - Six months after intervention } \\
\text { PHQ-9 scores improved. }\end{array}$ \\
\hline & & & & & & $\begin{array}{l}\text { - Significant increase in Firmicutes } \\
\text { counts and Bacteroides } \\
\text { significant reduced }\end{array}$ \\
\hline \multirow{2}{*}{$\begin{array}{l}\text { De Clerq } \\
\text { et al. } 2019 \\
{[67]}\end{array}$} & \multirow{2}{*}{$\begin{array}{l}1 \text { female AN } \\
\text { patient, } 26 \\
\text { years old }\end{array}$} & \multirow{2}{*}{$\begin{array}{l}\text { Case report, pre- } \\
\text { and post- } \\
\text { intervention } \\
\text { assessment }\end{array}$} & \multirow[t]{2}{*}{ Single duodenal FMT } & \multirow{2}{*}{$\begin{array}{l}\text { Unrelated } \\
\text { female donor } \\
\text { with BMl of } 25\end{array}$} & \multirow{2}{*}{$\begin{array}{l}\text { BMl, caloric } \\
\text { intake }\end{array}$} & - Increase in BMI post-intervention \\
\hline & & & & & & $\begin{array}{l}\text { - No significant differences in gut } \\
\text { microbiota composition after FMT }\end{array}$ \\
\hline \multirow[t]{2}{*}{$\begin{array}{l}\text { Huang et } \\
\text { al. } 2019 \\
{[45]}\end{array}$} & \multirow[t]{2}{*}{$\begin{array}{l}30(18 \mathrm{M}, 12 \mathrm{~F}) \\
\text { refractory IBS } \\
\text { patients, Mean } \\
\text { age: } 44 \text { years } \\
\text { old }\end{array}$} & \multirow[t]{2}{*}{$\begin{array}{l}\text { Pre- and post } \\
\text { intervention } \\
\text { assessment with } \\
1,3 \text {, and } 6 \\
\text { month follow- } \\
\text { ups }\end{array}$} & \multirow[t]{2}{*}{$\begin{array}{l}\text { Two to three FMT } \\
\text { procedures (done every } \\
\text { other day) via colonoscopy }\end{array}$} & \multirow[t]{2}{*}{$\begin{array}{l}\text { Healthy } \\
\text { volunteers aged } \\
8-35\end{array}$} & \multirow[t]{2}{*}{$\begin{array}{l}\text { IBS-QOL, IBS- } \\
\text { SSS, GSRS, } \\
\text { HAM-A and } \\
\text { HAM-D }\end{array}$} & $\begin{array}{l}\text { - Significantly improved GI } \\
\text { symptoms and alleviated } \\
\text { depression and anxiety as } \\
\text { indicated by IBS-QOL, IBS-SSS, } \\
\text { GSRS, HAM-A and HAM-D scores, } \\
1 \text { and } 3 \text { months post-FMT }\end{array}$ \\
\hline & & & & & & $\begin{array}{l}\text { - Increase in Verrucomincrobia and } \\
\text { Euryarchaeota at phyla level and } \\
\text { increase in Methanobrevibacter } \\
\text { and Akkermansia at the genus } \\
\text { level, at } 1 \text { month after FMT } \\
\text { compared to before FMT }\end{array}$ \\
\hline \multirow[t]{2}{*}{$\begin{array}{l}\text { Mazzawi } \\
\text { et al. [46] }\end{array}$} & \multirow[t]{2}{*}{$\begin{array}{l}13(9 \mathrm{M}, 4 \mathrm{~F}) \mathrm{IBS} \\
\text { patients, Mean } \\
\text { age: } 32 \text { years } \\
\text { old }\end{array}$} & \multirow[t]{2}{*}{$\begin{array}{l}\text { Open label, pilot } \\
\text { study }\end{array}$} & \multirow[t]{2}{*}{$\begin{array}{l}\text { Single duodenal FMT via } \\
\text { gastroscope }\end{array}$} & \multirow[t]{2}{*}{$\begin{array}{l}\text { Healthy donors, } \\
\text { aged } 20-42\end{array}$} & \multirow[t]{2}{*}{$\begin{array}{l}\text { IBS-SQ, IBS- } \\
\text { SSS, EPQ-N-12, } \\
\text { and HAD }\end{array}$} & $\begin{array}{l}\text { - Scores of all questionnaires } \\
\text { improved significantly at all } \\
\text { follow-up time points and lasted } \\
\text { up to } 28 \text { weeks }\end{array}$ \\
\hline & & & & & & $\begin{array}{l}\text { - Patients' microbiota compositions } \\
\text { became more similar to donors } \\
\text { after FMT }\end{array}$ \\
\hline \multirow[t]{4}{*}{$\begin{array}{l}\text { Mizuno et } \\
\text { al. } 2017 \\
{[44]}\end{array}$} & \multirow[t]{4}{*}{$\begin{array}{l}10(7 \mathrm{M}, 3 \mathrm{~F}) \\
\text { refractory IBS } \\
\text { patients, Mean } \\
\text { age: } 40.1 \text { years } \\
\text { old }\end{array}$} & \multirow[t]{4}{*}{$\begin{array}{l}\text { Single arm, open } \\
\text { label, non- } \\
\text { randomized } \\
\text { study with 12- } \\
\text { week follow-up }\end{array}$} & \multirow[t]{4}{*}{$\begin{array}{l}\text { Single time FMT via } \\
\text { colonoscopy }\end{array}$} & \multirow{4}{*}{$\begin{array}{l}\text { Healthy relatives } \\
\text { in second- } \\
\text { degree } \\
\text { relationship, } \\
\text { Mean age: } 52 \\
\text { years }\end{array}$} & \multirow[t]{4}{*}{$\begin{array}{l}\text { HAM-A, HAM- } \\
\text { D }\end{array}$} & $\begin{array}{l}\text { - The HAM-D score significantly } \\
\text { improved } 4 \text { weeks after FMT but } \\
\text { returned to the baseline level at } \\
12 \text { weeks }\end{array}$ \\
\hline & & & & & & $\begin{array}{l}\text { - When evaluated with HAM-A, the } \\
\text { GI symptoms significantly } \\
\text { improved from before FMT to } 12 \\
\text { weeks after in responders, but } \\
\text { not in non-responders }\end{array}$ \\
\hline & & & & & & $\begin{array}{l}\text { - Significant increase in microbial } \\
\text { diversity from before treatment } \\
\text { to week } 4\end{array}$ \\
\hline & & & & & & $\begin{array}{l}\text { - Significant relationship between } \\
\text { diversity and response to } \\
\text { treatment at week } 4 \text { but not } \\
\text { before treatment }\end{array}$ \\
\hline \multirow{3}{*}{$\begin{array}{l}\text { Xie et al. } \\
2019[47]\end{array}$} & \multirow{3}{*}{$\begin{array}{l}1 \text { male MDD } \\
\text { patient with } \\
\text { alopecia and Gl } \\
\text { symptoms, } 86 \\
\text { years old }\end{array}$} & \multirow{3}{*}{$\begin{array}{l}\text { Case report, pre- } \\
\text { and post- } \\
\text { intervention } \\
\text { assessment }\end{array}$} & \multirow{3}{*}{$\begin{array}{l}\text { Six rounds of FMT via } \\
\text { colonoscopy }\end{array}$} & \multirow{3}{*}{$\begin{array}{l}\text { 22-year old } \\
\text { healthy male } \\
\text { donor }\end{array}$} & \multirow[t]{3}{*}{ HAM-D } & - Improved depressive symptoms \\
\hline & & & & & & $\begin{array}{l}\text { - Improved appetite and no } \\
\text { abdominal pain or distension, } \\
\text { increased BMI. }\end{array}$ \\
\hline & & & & & & $\begin{array}{l}\text { - Improved hair growth without } \\
\text { any hair loss treatments }\end{array}$ \\
\hline $\begin{array}{l}\text { Kurokawa } \\
\text { et al. } 2018 \\
{[48]}\end{array}$ & $\begin{array}{l}17(8 \mathrm{M}, 9 F) \text { IBS } \\
\text { patients, Mean } \\
\text { age: } 43.41\end{array}$ & $\begin{array}{l}\text { Single arm, non- } \\
\text { randomized, } \\
\text { open label, } \\
\text { observational } \\
\text { study }\end{array}$ & $\begin{array}{l}\text { Single time FMT, via } \\
\text { colonoscopy }\end{array}$ & $\begin{array}{l}\text { Healthy relatives } \\
\text { in second- } \\
\text { degree } \\
\text { relationship, } \\
\text { Mean age: } 51.41\end{array}$ & $\begin{array}{l}\text { HAM-D and } \\
\text { subscale of } \\
\text { sleep-related } \\
\text { items, HAM-A, } \\
\text { and QIDS }\end{array}$ & $\begin{array}{l}\text { - Significant improvement in HAM- } \\
\text { D total and sleep subscale score, } \\
\text { HAM-A, and QIDS after FMT, at } \\
\text { times even without Gl symptoms } \\
\text { improvement }\end{array}$ \\
\hline & & & & & & $\begin{array}{l}\text { - Significant increase in } \\
\text { microbiome diversity after FMT }\end{array}$ \\
\hline Johnsen & 85 IBS (non- & Double-blind, & FMT (frozen or fresh) using & Frozen or fresh & Fatigue & - Clinical effect on QoL and fatigue \\
\hline
\end{tabular}


Table 4 Clinical studies (Continued)

\begin{tabular}{|c|c|c|c|c|c|c|}
\hline Study & $\begin{array}{l}\text { Sample } \\
\text { characteristics }\end{array}$ & Study design & Intervention & Donor & Measurement & Key findings and conclusions \\
\hline \multirow[t]{3}{*}{$\begin{array}{l}\text { et al. } 2020 \\
\text { [49] }\end{array}$} & \multirow{3}{*}{$\begin{array}{l}\text { constipated) } \\
\text { patients } \\
\text { between } 18 \\
\text { and } 75 \text { years of } \\
\text { age }\end{array}$} & \multirow[t]{3}{*}{$\begin{array}{l}\text { Randomized } \\
\text { Controlled Trial, } \\
\text { Parallel group }\end{array}$} & \multirow{3}{*}{$\begin{array}{l}\text { health donors or using } \\
\text { patient's own feces, } \\
\text { delivered to cecum of IBS } \\
\text { patients via colonoscope }\end{array}$} & \multirow[t]{3}{*}{$\begin{array}{l}\text { feces from } \\
\text { healthy donors }\end{array}$} & \multirow[t]{3}{*}{$\begin{array}{l}\text { Impact Scale } \\
\text { (FIS), IBS-QoL, } \\
\text { IBS-SSS }\end{array}$} & $\begin{array}{l}\text { six months after treatment, with } \\
\text { waning effect from six to twelve } \\
\text { months, }\end{array}$ \\
\hline & & & & & & $\begin{array}{l}\text { - Transient treatmnet effect seen in } \\
\text { individuals with other functional } \\
\text { disorders. }\end{array}$ \\
\hline & & & & & & $\begin{array}{l}\text { - Absence of other self reported } \\
\text { functional disorders and presence } \\
\text { of depression at baseline is } \\
\text { suggested to predict a lasting } \\
\text { effect of FMT in QoL and fatigue, } \\
\text { respectively }\end{array}$ \\
\hline
\end{tabular}

\section{Abbreviations}

GBA: Gut-Brain Axis; Gl: Gastrointestinal; CNS: Central Nervous System; ANS: Autonomic Nervous System; IBS: Irritable Bowel Syndrome; BDNF: BrainDerived Neurotrophic Factor; FMT: Fecal Microbiota Transplant; GAD: Generalized Anxiety Disorder; MDD: Major Depressive Disorder; PRISMA: Preferred Reporting Items for Systematic Reviews and MetaAnalyses; CUMS: Chronic Unpredictable Mild Stress; NLRP3: NOD-, LRR- and pyrin domain-containing protein 3; CSC: Chronic Subordinate Colony; SHC: Non-stressful Single Housing Colony; FSL: Flinders Sensitive Line Rats; FRL: Flinders Resistant Line Rats; LL/Resilient: Long Latency/Resilient; SCl: Spinal Cord Injury; SNI: Spinal Neuropathic Injury; SL/Nulnerable: Short Latency/Vulnerable; GF: Germ Free; HAM-D: Hamilton Depression Rating Scale; PHQ-9: Patient Health Questionnaire-9; QIDS: Quick Inventory of Depressive Symptomatology; HADS(-A/D): Hospital Anxiety and Depression Scale (-Anxiety/Depression Specific); HAM-A: Hamilton Anxiety Rating Scale; EPQ-N-12: Eynsek Personality Questionnaire-Neuroticism; IBS-QOL: Irritable Bowel Syndrome - Quality of Life; SSRI: Selective Serotonin Reuptake Inhibitors; EC: Enterochromaffin Cells; SCFA: Short-chain Fatty Acids

\section{Acknowledgements}

No acknowledgements.

\section{Authors' contributions}

All authors have read and approved the manuscript. Study selection was completed by ACM, CW, and RM. ACM and EF assessed the data for potential analysis, and wrote a first draft of the text, while all authors contributed to subsequent drafts. ACM facilitated article submission.

\section{Funding}

No funding was received for this research.

\section{Availability of data and materials}

All data analysed for and presented in this paper are from the twenty-one studies we reviewed. The data is accessible via referenced articles.

\section{Ethics approval and consent to participate}

Given the data is collected from publicly available information, research ethics board review is not required for systematic reviews. There was no informed consent required as there was no interaction with the participants in this study.

\section{Consent for publication}

Not applicable.

\section{Competing interests}

RM has received consulting and speaking honoraria from Allergan, Janssen, KYE Lundbeck, Otsuka, Pfizer and Sunovion, and research grants from CAN-BIND, $\mathrm{CIHR}$, Janssen, Lallemand Health Solutions, Lundbeck, Nubiyota, OBI, OMHF and Pfizer. CW has received study funding from Lallemand Health Solutions.

\section{Author details}

${ }^{1}$ Department of Psychiatry, Queen's University, 752 King St. West, Kingston, ON K7L 4X3, Canada. ${ }^{2}$ Providence Care Hospital, 752 King St. West, Kingston, ON K7L 4X3, Canada. ${ }^{3}$ Centre for Neuroscience Studies, Queen's University, 18 Stuart St., Kingston, ON K7L 3N6, Canada. ${ }^{4}$ Department of Psychology, Queen's University, 62 Arch St., Kingston K7L 3L3, ON, Canada.

Received: 27 February 2020 Accepted: 4 May 2020

Published online: 15 June 2020

\section{References}

1. Cryan JF, Dinan TG. Mind-altering microorganisms: the impact of the gut microbiota on brain and behaviour. Nat Rev Neurosci. 2012;13(10):701-12 https://doi.org/10.1038/nrn3346.

2. Martin R, et al. Early-life events, including mode of delivery and type of feeding, siblings and gender, shape the developing gut microbiota. PLoS One. 2016;11(6):e0158498 https://doi.org/10.1371/journal.pone. 0158498.

3. Cussotto S, Clarke G, Dinan TG, Cryan JF. Psychotropics and the microbiome: a chamber of secrets .... Psychopharmacology. 2019;236(5): 1411-32 https://doi.org/10.1007/s00213-019-5185-8.

4. Foster JA, McVey Neufeld K-A. Gut-brain axis: how the microbiome influences anxiety and depression. Trends Neurosci. 2013;36(5):305-12 https://doi.org/10.1016/j.tins.2013.01.005.

5. O'Hara AM, Shanahan F. The gut flora as a forgotten organ. EMBO Rep. 2006;7(7):688-93 https://doi.org/10.1038/sj.embor.7400731.

6. Zhu B, Wang X, Li L. Human gut microbiome: the second genome of human body. Protein Cell. 2010;1(8):718-25 https://doi.org/10.1007/s13238-010-0093-z.

7. Stilling RM, Dinan TG, Cryan JF. Microbial genes, brain \& behaviour epigenetic regulation of the gut-brain axis. Genes Brain Behav. 2014;13(1): 69-86 https://doi.org/10.1111/gbb.12109.

8. Dash S, Clarke G, Berk M, Jacka FN. The gut microbiome and diet in psychiatry: focus on depression. Curr Opin Psychiatry. 2015;28(1):1 https:// doi.org/10.1097/YCO.0000000000000117.

9. Liu Y, et al. Similar fecal microbiota signatures in patients with diarrheapredominant irritable bowel syndrome and patients with depression. Clin Gastroenterol Hepatol. 2016;14(11):1602-1611.e5 https://doi.org/10.1016/j. cgh.2016.05.033.

10. Sudo N, et al. Postnatal microbial colonization programs the hypothalamicpituitary-adrenal system for stress response in mice. J Physiol. 2004:558(Pt 1):263-75 https://doi.org/10.1113/jphysiol.2004.063388

11. Heijtz RD, et al. Normal gut microbiota modulates brain development and behavior. Proc Natl Acad Sci U S A. 2011;108(7):3047-52 https://doi.org/10. 1073/pnas.1010529108

12. Neufeld KM, Kang N, Bienenstock J, Foster JA. Reduced anxiety-like behavio and central neurochemical change in germ-free mice. Neurogastroenterol Motil. 2011;23(3):255-e119 https://doi.org/10.1111/j.1365-2982.2010.01620.x.

13. Zhang F, Luo W, Shi Y, Fan Z, Ji G. Should we standardize the 1,700-year-old fecal microbiota transplantation? Am J Gastroenterol. 2012;107(11):1755 author reply p.1755-1756. https://doi.org/10.1038/ajg.2012.251. 
14. de Groot PF, Frissen MN, de Clercq NC, Nieuwdorp M. Fecal microbiota transplantation in metabolic syndrome: history, present and future. Gut Microbes. 2017;8(3):253-67 https://doi.org/10.1080/19490976.2017.1293224.

15. Huang $\mathrm{H}$, et al. Fecal microbiota transplantation to treat Parkinson's disease with constipation: a case report. Medicine. 2019a;98(26):e16163 https://doi. org/10.1097/MD.0000000000016163.

16. Kang D-W, et al. Microbiota transfer therapy alters gut ecosystem and improves gastrointestinal and autism symptoms: an open-label study. Microbiome. 2017;5(1):10 https://doi.org/10.1186/s40168-016-0225-7.

17. Makkawi S, Camara-Lemarroy C, Metz L. Fecal microbiota transplantation associated with 10 years of stability in a patient with SPMS. Neurol Neuroimmunol Neuroinflamm. 2018;5(4):e459 https://doi.org/10.1212/NXI. 0000000000000459 .

18. Meyyappan AC, Milev R. The safety, efficacy, and tolerability of microbial ecosystem therapeutic-2 in people with major depression and/or generalized anxiety disorder: phase 1, open label study protocol. JMIR Res Protoc (forthcoming). https://doi.org/10.2196/17223.

19. American Psychiatric Association. Depressive disorders and anxiety disorders. In: Diagnostic and statistical manual of mental disorders. 5th ed. Philadelphia: American Psychiatric Association; 2013. p. 93-128.

20. Moher D, Liberati A, Tetzlaff J, Altman DG, PRISMA Group. Preferred reporting items for systematic reviews and meta-analyses: the PRISMA statement. PLoS Med. 2009;6(7):e1000097 https://doi.org/10.1371/journal.pmed.1000097.

21. Li N, et al. Fecal microbiota transplantation from chronic unpredictable mild stress mice donors affects anxiety-like and depression-like behavior in recipient mice via the gut microbiota-inflammation-brain axis. Stress. 2019; 22(5):592-602 https://doi.org/10.1080/10253890.2019.1617267.

22. Lv W, et al. The gut microbiome modulates the changes in liver metabolism and in inflammatory processes in the brain of chronic unpredictable mild stress rats. Oxidative Med Cell Longev. 2019;2019:1-14 https://doi.org/10. 1155/2019/7902874

23. Siopi $\mathrm{E}_{\text {, et }}$ al. Changes in gut microbiota by chronic stress impair the efficacy of fluoxetine. Cell Rep. 2020;30(11):3682-3690.e6 https://doi.org/10. 1016/j.celrep.2020.02.099

24. Pearson-Leary J, et al. The gut microbiome regulates the increases in depressive-type behaviors and in inflammatory processes in the ventral hippocampus of stress vulnerable rats. Mol Psychiatry. 2019;25:1-12 https:// doi.org/10.1038/s41380-019-0380-x

25. Langgartner $\mathrm{D}$, et al. The role of the intestinal microbiome in chronic psychosocial stress-induced pathologies in male mice. Front Behav Neurosci. 2018;12:252 https://doi.org/10.3389/fnbeh.2018.00252.

26. Alcocer-Gómez E, et al. NLRP3 inflammasome is activated in mononuclear blood cells from patients with major depressive disorder. Brain Behav Immun. 2014;36:111-7 https://doi.org/10.1016/j.bbi.2013.10.017.

27. Zhang $Y$, et al. Involvement of inflammasome activation in lipopolysaccharide-induced mice depressive-like behaviors. CNS Neurosci Ther. 2014;20(2):119-24 https://doi.org/10.1111/cns.12170.

28. Zhang Y, et al. Gut microbiota from NLRP3-deficient mice ameliorates depressive-like behaviors by regulating astrocyte dysfunction via circHIPK2. Microbiome. 2019;7(1):116 https://doi.org/10.1186/s40168-019-0733-3.

29. Xiao $\mathrm{H}$, et al. Gut microbiota modulates alcohol withdrawal-induced anxiety in mice. Toxicol Lett. 2018;287:23-30 https://doi.org/10.1016/j.toxlet.2018.01.021.

30. Jiang Y, Liu Y, Gao M, Xue M, Wang Z, Liang H. Nicotinamide riboside alleviates alcohol-induced depression-like behaviours in C57BL/6J mice by altering the intestinal microbiota associated with microglial activation and BDNF expression. Food Funct. 2020;11(1):378-91 https://doi.org/10.1039/ C9FO01780A

31. Overstreet $\mathrm{DH}$, Wegener $\mathrm{G}$. The flinders sensitive line rat model of depression--25 years and still producing. Pharmacol Rev. 2013;65(1):143-55 https://doi.org/10.1124/pr.111.005397.

32. Tillmann S, Abildgaard A, Winther G, Wegener G. Altered fecal microbiota composition in the Flinders sensitive line rat model of depression. Psychopharmacology. 2019;236(5):1445-57 https://doi.org/10.1007/s00213018-5094-2.

33. Schmidt EKA, Torres-Espin A, Raposo PJF, et al. Fecal transplant prevents gut dysbiosis and anxiety-like behaviour after spinal cord injury in rats. PLoS One. 2020;15(1):e0226128 https://doi.org/10.1371/journal.pone.0226128.

34. Kelly JR, et al. Transferring the blues: depression-associated gut microbiota induces neurobehavioural changes in the rat. J Psychiatr Res. 2016;82:109_ 18 https://doi.org/10.1016/j.jpsychires.2016.07.019.
35. Zheng P, et al. Gut microbiome remodeling induces depressive-like behaviors through a pathway mediated by the host's metabolism. Mol Psychiatry. 2016;21(6):786-96 https://doi.org/10.1038/mp.2016.44.

36. Huang $\mathrm{C}$, et al. Proteomic analysis of olfactory bulb suggests CACNA1E as a promoter of CREB signaling in microbiota-induced depression. J Proteome. 2019b:194:132-47 https://doi.org/10.1016/j.jprot.2018.11.023.

37. Liu S, Guo R, Liu F, Yuan Q, Yu Y, Ren F. Gut microbiota regulates depression-like behavior in rats through the neuroendocrine-immunemitochondrial pathway. Neuropsychiatr Dis Treat. 2020;16:859-69 https:// doi.org/10.2147/NDT.S243551.

38. Petrakis IL, Gonzalez G, Rosenheck R, Krystal JH. Comorbidity of alcoholism and psychiatric disorders. Alcohol Res Health. 2002;26(2):81-9.

39. Zhao W, et al. Transplantation of fecal microbiota from patients with alcoholism induces anxiety/depression behaviors and decreases brain mGluR1/PKC $\varepsilon$ levels in mouse; 2019. p. 17.

40. $\mathrm{Xu} \mathrm{Z}$, et al. Fecal microbiota transplantation from healthy donors reduced alcohol-induced anxiety and depression in an animal model of chronic alcohol exposure. Chin J Phys. 2018;61(6):360-71.

41. Hudson JI, Hiripi E, Pope HG, Kessler RC. The prevalence and correlates of eating disorders in the National Comorbidity Survey Replication. Biol Psychiatry. 2007;61(3):348-58 https://doi.org/10.1016/j.biopsych.2006.03.040.

42. Hata $T$, et al. The gut microbiome derived from anorexia nervosa patients impairs weight gain and behavioral performance in female mice. Endocrinology. 2019;160(10):2441-52 https://doi.org/10.1210/en.2019-00408.

43. De Palma G, et al. Transplantation of fecal microbiota from patients with irritable bowel syndrome alters gut function and behavior in recipient mice. Sci Transl Med. 2017;9(379):eaaf6397 https://doi.org/10.1126/scitranslmed. aaf6397.

44. Mizuno S, et al. Bifidobacterium-rich fecal donor may be a positive predictor for successful fecal microbiota transplantation in patients with irritable bowel syndrome. Digestion. 2017;96(1):29-38 https://doi.org/10.1159/ 000471919

45. Huang HL, et al. Relief of irritable bowel syndrome by fecal microbiota transplantation is associated with changes in diversity and composition of the gut microbiota. J Dig Dis. 2019c;20(8):401-8 https://doi.org/10.1111/ 1751-2980.12756.

46. Mazzawi T, et al. The kinetics of gut microbial community composition in patients with irritable bowel syndrome following fecal microbiota transplantation. PLOS ONE. 2018;13(11):e0194904 https://doi.org/10.1371/ journal.pone.0194904.

47. Xie W-R, Yang X-Y, Xia HH-X, Wu L-H, He X-X. Hair regrowth following fecal microbiota transplantation in an elderly patient with alopecia areata: a case report and review of the literature. World J Clin Cases. 2019;7(19):3074-81 https://doi.org/10.12998/wjcc.v7.i19.3074.

48. Kurokawa S, et al. The effect of fecal microbiota transplantation on psychiatric symptoms among patients with irritable bowel syndrome, functional diarrhea and functional constipation: an open-label observational study. J Affect Disord. 2018;235:506-12 https://doi.org/10.1016/j.jad.2018.04.038

49. Johnsen $\mathrm{PH}$, Hilpüsch F, Valle PC, Goll R. The effect of fecal microbiota transplantation on IBS related quality of life and fatigue in moderate to severe non-constipated irritable bowel: secondary endpoints of a double blind, randomized, placebo-controlled trial. EBioMedicine. 2020;51:102562 https://doi.org/10.1016/j.ebiom.2019.11.023.

50. Treviño LA, Ruble MW, Treviño K, Weinstein LM, Gresky DP. Antidepressant medication prescribing practices for treatment of major depressive disorder. Psychiatr Serv. 2017;68(2):199-202 https://doi.org/10.1176/appi.ps.201600087.

51. Gershon MD. 5-Hydroxytryptamine (serotonin) in the gastrointestinal tract. Curr Opin Endocrinol Diab Obes. 2013;20(1):14-21 https://doi.org/10.1097/ MED.0b013e32835bc703.

52. Reigstad CS, et al. Gut microbes promote colonic serotonin production through an effect of short-chain fatty acids on enterochromaffin cells. FASEB J. 2015:29(4):1395-403 https://doi.org/10.1096/fj.14-259598.

53. Silva YP, Bernardi A, Frozza RL. The role of short-chain fatty acids from gut microbiota in gut-brain communication. Front Endocrinol. 2020;11:25 https://doi.org/10.3389/fendo.2020.00025.

54. van de Wouw $M_{\text {, et }}$ al. Short-chain fatty acids: microbial metabolites that alleviate stress-induced brain-gut axis alterations. J Physiol. 2018;596(20): 4923-44 https://doi.org/10.1113/JP276431.

55. Singh N, et al. Activation of Gpr109a, receptor for niacin and the commensal metabolite butyrate, suppresses colonic inflammation and 
carcinogenesis. Immunity. 2014;40(1):128-39 https://doi.org/10.1016/j. immuni.2013.12.007.

56. Erny D, et al. Host microbiota constantly control maturation and function of microglia in the CNS. Nat Neurosci. 2015;18(7):965-77 https://doi.org/10. 1038/nn.4030

57. Bauer ME, Teixeira AL. Inflammation in psychiatric disorders: what comes first? Ann N Y Acad Sci. 2019;1437(1):57-67 https://doi.org/10.1111/nyas.13712.

58. Inserra A, Rogers GB, Licinio J, Wong M-L. The microbiota-inflammasome hypothesis of major depression. Bioessays. 2018;40(9):e1800027 https://doi. org/10.1002/bies.201800027.

59. Bonaz B, Bazin T, Pellissier S. The vagus nerve at the interface of the microbiota-gut-brain axis. Front Neurosci. 2018;12:49 https://doi.org/10. 3389/fnins.2018.00049.

60. Breit S, Kupferberg A, Rogler G, Hasler G. Vagus nerve as modulator of the brain-gut axis in psychiatric and inflammatory disorders. Front Psychiatry. 2018:9:44 https://doi.org/10.3389/fpsyt.2018.00044.

61. Garcia-Toro M, Medina E, Galan JL, Gonzalez MA, Maurino J. Treatment patterns in major depressive disorder after an inadequate response to firstline antidepressant treatment. BMC Psychiatry. 2012;12:143 https://doi.org/ 10.1186/1471-244X-12-143.

62. Stahl SM. Mechanism of action of serotonin selective reuptake inhibitors Serotonin receptors and pathways mediate therapeutic effects and side effects. J Affect Disord. 1998;51(3):215-35 https://doi.org/10.1016/s01650327(98)00221-3.

63. Lloyd-Price J, Abu-Ali G, Huttenhower C. The healthy human microbiome. Genome Med. 2016;8(1) https://doi.org/10.1186/s13073-016-0307-y.

64. Turnbaugh PJ, Ley RE, Hamady M, Fraser-Liggett CM, Knight R, Gordon J. The human microbiome project. Nature. 2007;449(7164):804-10 https://doi. org/10.1038/nature06244

65. Huttenhower $\mathrm{C}$, et al. Structure, function and diversity of the healthy human microbiome. Nature. 2012;486(7402):207-14 https://doi.org/10.1038/ nature11234.

66. Cai T, Shi X, Yuan L, Tang D, Wang F. Fecal microbiota transplantation in an elderly patient with mental depression. Int Psychogeriatr. 2019;31(10):15256 https://doi.org/10.1017/S1041610219000115.

67. de Clercq NC, Frissen MN, Davids M, Groen AK, Nieuwdorp M. Weight Gain after Fecal Microbiota Transplantation in a Patient with Recurrent Underweight following Clinical Recovery from Anorexia Nervosa. Psychother Psychosom. 2019;88(1):58-60 https://doi.org/10.1159/000495044.

68. Yang $C$, et al. Key role of gut microbiota in anhedonia-like phenotype in rodents with neuropathic pain. Transl Psychiatry. 2019;9(1):1-11 https://doi. org/10.1038/s41398-019-0379-8.

69. Chen K, Fu Y, Wang Y, et al. Therapeutic Effects of the In Vitro Cultured Human Gut Microbiota as Transplants on Altering Gut Microbiota and Improving Symptoms Associated with Autism Spectrum Disorder. Microb Ecol. 2020; https://doi.org/10.1007/s00248-020-01494-w.

\section{Publisher's Note}

Springer Nature remains neutral with regard to jurisdictional claims in published maps and institutional affiliations.

Ready to submit your research? Choose BMC and benefit from:

- fast, convenient online submission

- thorough peer review by experienced researchers in your field

- rapid publication on acceptance

- support for research data, including large and complex data types

- gold Open Access which fosters wider collaboration and increased citations

- maximum visibility for your research: over $100 \mathrm{M}$ website views per year

At BMC, research is always in progress.

Learn more biomedcentral.com/submissions 